\title{
Factors Affecting Efficiency of Biosorption of Fe (III) and Zn (II) by Ulva lactuca and Corallina officinalis and Their Activated Carbons
}

\author{
Mahy M. Ameen 1(D), Abdelraouf A. Moustafa 1,*, Jelan Mofeed ${ }^{2,3}$, Mustapha Hasnaoui ${ }^{4}$, \\ Oladokun Sulaiman Olanrewaju ${ }^{5}$, Umberto Lazzaro ${ }^{6}$ and Giulia Guerriero $6,7, *$ (D)
}

check for updates

Citation: Ameen, M.M.; Moustafa, A.A.; Mofeed, J.; Hasnaoui, M.; Olanrewaju, O.S.; Lazzaro, U.; Guerriero, G. Factors Affecting Efficiency of Biosorption of Fe (III) and Zn (II) by Ulva lactuca and Corallina officinalis and Their Activated Carbons. Water 2021, 13, 3421. https://doi.org/10.3390/ w13233421

Academic Editor: Ana Iglesias

Received: 23 October 2021

Accepted: 28 November 2021

Published: 3 December 2021

Publisher's Note: MDPI stays neutral with regard to jurisdictional claims in published maps and institutional affiliations.

Copyright: (c) 2021 by the authors. Licensee MDPI, Basel, Switzerland. This article is an open access article distributed under the terms and conditions of the Creative Commons Attribution (CC BY) license (https:/ / creativecommons.org/licenses/by/ $4.0 /)$.
1 Botany Department, Faculty of Science, Suez Canal University, Ismailia 41522, Egypt; yamen_yassen84@yahoo.com

2 Aquatic Environmente Department, Faculty of Fish Recourses, Suez Canal University, Ismailia 41511, Egypt; jelanmofeed@hotmail.com

3 Faculty of Science, King Salman International University, Ras Sudr 46612, Egypt

4 Environmental Engineering Team, Department of life Sciences, Faculty of Sciences and Techniques, University of Sultan Moulay Slimane, Beni Mellal P.O. Box 523, Morocco; m.hasnaoui@usms.ma

5 Institute of Hydraulic and Water Resource Management, RWTH Aachen University, 55 Templergraben, 52056 Aachen, Germany; seanexus1@gmail.com

6 Comparative Endocrinology Laboratories (EClab), Department of Biology, University of Naples Federico II, Via Cinthia 26, 80126 Naples, Italy; lazzaro.eclab@gmail.com

7 Interdepartmental Research Center for Environment (I.R.C.Env.), University of Naples Federico II, Via Mezzocannone 16, 80134 Naples, Italy

* Correspondence: raoufmoustafa2@hotmail.com (A.A.M.); giulia.guerriero@unina.it (G.G.)

\begin{abstract}
The removal of heavy metals from industrial waste has become crucial in order to maintain water quality levels that are suitable for environmental and species reproductive health. The biosorption of $\mathrm{Zn}^{+2}$ and $\mathrm{Fe}^{+3}$ ions from aqueous solution was investigated using Ulva lactuca green algal biomass and Corallina officinalis red algal biomass, as well as their activated carbons. The effects of biosorbent dosage, $\mathrm{pH}$, contact time, initial metal concentration, and temperature on biosorption were evaluated. The maximum monolayer capacity of Ulva lactuca and Corallina officinalis dry algal powder and algal activated carbon was reached at $\mathrm{pH} 5$ and 3 for $\mathrm{Zn}^{+2}$ and $\mathrm{Fe}^{+3}$, respectively, while the other factors were similar for both algae, which were: contact time $120 \mathrm{~min}$, adsorbent dose $1 \mathrm{~g}$, temperature $40^{\circ} \mathrm{C}$ and initial concentrations of metal ion $50 \mathrm{mg} \cdot \mathrm{L}^{-1}$. The batch experimental data can be modelled using the Langmuir and Freundlich isotherm models. Thermodynamic characteristics revealed that the adsorption process occurs naturally and is endothermic and spontaneous. For the adsorption of $\mathrm{Zn}^{+2}$ and $\mathrm{Fe}^{+3}$ ions, the value of $\mathrm{G}^{\circ}$ was found to be negative, confirming the practicality of the spontaneous adsorption process, which could be helpful for remediation in the era of temperature increases.
\end{abstract}

Keywords: aquatic organisms; Ulva lactuca; Corallina officinalis; activated carbon; biosorption; thermodynamics; isotherm; temperature changes effect; bioremediation; sustainability

\section{Introduction}

Environmental concerns have developed as a result of greater industrial expansion to close the gap in human demands [1]. Water pollution is a prevalent form of pollution that the planet is grappling with at the moment, and is considered one of the highest risk factors for sickness, disease and biodiversity loss [2-5]. According to global databases and statistics, heavy element contamination is among the most serious of the environmental concerns due to its very detrimental effects on environmental balance, human feeding, and species sustainability [6-9], especially under climate change conditions [10-12]. Wastewater can contain a wide variety of heavy metals, especially waste that has resulted mainly from industrialization, such as $\mathrm{Cu}, \mathrm{Cr}, \mathrm{Cd}, \mathrm{Fe}, \mathrm{Zn}$ and $\mathrm{Hg}$ [5,13-17]. Zinc and iron are very 
common pollutants in the environment; their occurrence negatively affects water ecology, and consequently, humans [18].

Mining and smelting activities in addition to the petrochemical, medical drugs and fertilizer industries are some of the primary sources of heavy-metal pollution $[11,13,19,20]$. High zinc and iron levels, on the other hand, can cause serious health issues such as stomach pains, vomiting, skin irritations, anemia, nausea, and asymmetry [21,22]. Ion-exchange, chemical precipitation, membrane filtration, adsorption, and electrochemical treatment technologies are all available to extract and separate these heavy metals from water and wastewater [23]. Because it is frequently employed in wastewater treatment procedures, adsorption is one of the safest, easiest, and most cost-effective approaches [24]. Heavy metals are a dangerous problem due to their non-biodegradable nature and excessive environmental accumulation $[25,26]$. Accumulation of heavy metals in the food chain influences the health of living organisms, particularly humans [27-30]. To maintain water quality levels that are acceptable for environmental and human health, it has become critical to remove heavy metals from mine drainage and other industrial waste.

Traditional techniques such as reverse osmosis, electrodialysis, ultrafiltration, the industrial ion-exchange process, and chemical precipitation are used to remove heavy metals from industrial wastewater [31-33]. Unfortunately, the majority of these commonly used methods are constrained by critical barriers such as low selectivity, high cost, inefficient removal, significant energy consumption, and the inability to handle massive amounts of hazardous waste $[34,35]$. The adsorption method is the most extensively utilized of all the removal processes mentioned above, since it is a low-cost, environmentally friendly, reversible, and rapid-acting technology that can be readily used in many circumstances to control pollution [36-38]. Activated carbon is known to be a highly effective absorbent material in the removal of a wide range of organic and inorganic pollutants and gases from various media and is the most commonly utilized material for the treatment of wastewater contamination [39-41]. However, the cost of the materials required to produce higher-quality activated carbon is considerable [42]. Therefore, establishing low-cost activated-carbon solutions is vital for the removal of heavy metals from wastewater $[43,44]$.

Generally, any natural material has its adsorptive properties and can be used for heavy-metal removal, such as the microbial cultures of fungi, algae and plants [45]. The performance of different natural biosorbents, on the other hand, is dependent on the characteristics of the biomass as well as the affinity of the target heavy metal. The biosorption mechanism may be based on chemical adsorption that involves covalent binding between cationic ions and the negative charge on the cell surface and/or on physical adsorption in the form of electrostatic attraction.

Therefore, the search for cost-effective, environmentally friendly, and widely available adsorbents, particularly of biological, natural materials, is presently the subject of intense research [46]. The ability to absorb heavy metals by using plants requires an acidic medium, which may affect the environmental balance in the long run, in addition to increasing the economic cost of the adsorption process; moreover, it also competes with agricultural crops in the exploited agricultural area [47]. On the other hand, bacteria and fungi may not be safe enough to be used as biosorbents on a large economic scale [48]. Zayadi and Othma [49], in a study that focused on the bioremediation of Fe and $\mathrm{Zn}$ ions from aqueous solution using Tilapia fish scales, reported that biosorption efficiency was $64.2 \%$ and $79.4 \%$, respectively, for these ions. However, efficiency reached $85 \%$ and $89 \%$, respectively, after two hours of contact with dead cyanobacterial [50]. In another study, the biosorption efficiency of zinc by Sargassum lipendula was approximately $41.8 \%$, while it was $27.5 \%$ and $61.8 \%$ using anaerobic biological sludge and Bacillus firmus, respectively [51].

Algal biomasses represent a rich source of biosorption material that is capable of accumulating a high metal content while being ecologically safer and needing relatively inexpensive processing. Due to the presence of proteins, hetero-polysaccharides or lipids in the algal cell-wall structure, as well as large surface-area-to-volume ratios, these biomasses have high metal-binding capacities [48]. Marine macro-algae possess strong metal-biosorption 
capacities due to the presence of active functional groups on the surface of their cell walls. Using marine macroalgae-activated carbon provides a number of advantages, including low cost, wide availability, and high metal-binding capability [52,53]. The marine green alga Ulva lactuca and the red alga Corallina officinalis are the two species that were tested in this study for the removal zinc and iron ions from an aqueous solution. Both of these algae are available in considerable quantities and are used for many other environmental as well as human purposes such as "functional foods" or "nutraceuticals", etc. [54,55]. Furthermore, because of its high surface area, relatively simple structure, and modest and uniform distribution of binding sites, this material is very useful in heavy-metal processing [56,57], and it may be utilized directly for heavy-metal recovery as a biosorbent [56-58].

The main objective of this research was to use dried algal powder (DAP) and algal activated carbon (AAC) of Ulva lactuca and Corallina officinalis as biosorbents to eliminate $\mathrm{Zn}^{+2}$ and $\mathrm{Fe}^{+3}$ ions from aqueous solution. Additionally, the influence of several operating parameters such as temperature, adsorbent dosage, contact time, $\mathrm{pH}$ and initial concentration was investigated in order to evaluate the maximum adsorption capacity and the optimum adsorption conditions. Equilibrium isotherms and thermodynamic modelling were used to deduce the possible mechanism of the adsorption process.

\section{Materials and Methods}

\subsection{Collection of Algal Biomass}

Two macroalgal species, the green alga Ulva lactuca (L.) and the red alga Corallina officinalis (L.), were handpicked during mid-autumn at a depth of $0.2 \mathrm{~m}$ or less from the rocks of Alexandria's Eastern Harbor, which is a small, shallow, semi-circular basin located between longitudes $29^{\circ} 53^{\prime}$ and $29^{\circ} 54.4^{\prime} \mathrm{E}$ and latitudes $31^{\circ} 12^{\prime}$ and $31^{\circ} 13^{\prime} \mathrm{N}$. According to the rules of the Egyptian Environmental Affairs Agency (EEAA), the size of the collected living algal biomass samples (fresh weight) was strictly in order to maintain the bioconservation of the protected area. Both U. lactuca and C. officinalis were selected due to the commonly large quantities of their blooms. The algal biomass samples were collected according to the Londo scale [59] and identified at the genus and species levels based on their morphology and anatomy $[60,61]$.

\subsection{Preparation of Biosorbent}

Preparation of dried algal powder (DAP)

In order to remove sand, impurities, and salts, the algal samples were rinsed several times, first with excessive amounts of tap water and then with distilled water. The washed algal biomass was air-dried for $72 \mathrm{~h}$ before being oven-dried for $24 \mathrm{~h}$ at $60{ }^{\circ} \mathrm{C}$ until no further weight change was achieved. The biomass was then crushed and sieved into particles ranging in size from 0.2 to $1.0 \mathrm{~mm}$. The dried seaweeds were stored at room temperature away from light and moisture in a well-sealed amber-colored jar.

Algal activated carbon (AAC) preparation

In a stainless-steel reactor tube $(40 \times 600 \mathrm{~mm})$, the dried algal material was carbonized for $3 \mathrm{~h}$ at $600{ }^{\circ} \mathrm{C}$. The samples were soaked for $48 \mathrm{~h}$ in potassium hydroxide (in ratio: $3 \mathrm{~g}$ potassium hydroxide to $1 \mathrm{~g}$ carbonized sample). The samples were calcined at $800{ }^{\circ} \mathrm{C}$ for $3 \mathrm{~h}$. The activated carbon was rinsed multiple times with distilled water until a neutral filtrate was obtained. The washed samples were maintained for adsorption investigations after drying at $110^{\circ} \mathrm{C}$ [62].

\section{Adsorbate solutions (synthetic solution) preparation}

Stock standard solutions of $\mathrm{Fe}^{+3}$ and $\mathrm{Zn}^{+2}$ ions were prepared by dispersing $0.210 \mathrm{~g}$ of zinc sulfate $\left(\mathrm{ZnSO}_{4} .7 \mathrm{H}_{2} \mathrm{O}\right)$ and $0.249 \mathrm{~g}$ of ferrous sulphate $\left(\mathrm{FeSO}_{4} .7 \mathrm{H}_{2} \mathrm{O}\right)$ in 1 liter of water, respectively. In order to ensure purity, $\mathrm{Fe}^{+3}$ and $\mathrm{Zn}^{+2}$ ions were prepared with doubledeionized water. Hydrochloric acid $\left(0.1 \mathrm{~mol} . \mathrm{L}^{-1}\right)$ and sodium hydroxide $\left(0.1 \mathrm{~mol}^{-1} \mathrm{~L}^{-1}\right)$ were used to adjust the $\mathrm{pH}$. One-liter aliquots of this stock solution were used for all of the following adsorption tests. 


\subsection{Adsorption Procedure}

Determination of optimum $\mathrm{pH}$

In order to test the effect of $\mathrm{pH}$, the parameters of initial metal concentration, algal dose and contact time were set at $50 \mathrm{mg} . \mathrm{L}^{-1}, 1.0 \mathrm{~g} . \mathrm{L}^{-1}$ and $120 \mathrm{~min}$., respectively, at $38 \pm 1{ }^{\circ} \mathrm{C}$. The impact of $\mathrm{pH}$ was evaluated by varying $\mathrm{pH}$ from 2 to 8 for $\mathrm{Zn}^{+2}$ and from 1 to 6 for $\mathrm{Fe}^{+3}$ (the range was unaffected by the metal precipitation) [63]. The solutions were $\mathrm{pH}$-adjusted with $1 \mathrm{M} \mathrm{HCl}$ and $1 \mathrm{M} \mathrm{NaOH}$. The samples were assessed for the corresponding metal-ion concentration using an atomic absorption spectrophotometer (Analytikjena Model Nova350).

Determination of optimum biomass dosage

Different biomass weights $\left(0.20,0.50,0.75,1.0,1.5\right.$ and 2.0 g.L $\left.{ }^{-1}\right)$ were added to volumetric flasks containing $50 \mathrm{mg} . \mathrm{L}^{-1}$ of each metal solution in order to investigate the optimal biomass dose of each tested algae for heavy-metal biosorption. Flasks were shaken at $\mathrm{pH} 5$ for $\mathrm{Zn}^{+2}$ and $\mathrm{pH} 3$ for $\mathrm{Fe}^{+3}$ at $38 \pm 1{ }^{\circ} \mathrm{C}$ for 120 min., after which the samples were analyzed using AAS to determine the metal-ion concentration.

Determination of optimum contact time

One gram each of DAP and AAC were added to $50 \mathrm{mg} \cdot \mathrm{L}^{-1}$ of a heavy-metal solution that was adjusted to $\mathrm{pH} 5$ for $\mathrm{Zn}^{+2}$ and $\mathrm{pH} 3$ for $\mathrm{Fe}^{+3}$ at room temperature. Contact times of 30, 60, 90, 120, 180 and 240 min were tested. The mixtures were filtered and analyzed for metal-ion concentration using the AAS after each contact time.

Determination of optimum temperature

One gram each of DAP and AAC were added to $50 \mathrm{mg} \cdot \mathrm{L}^{-1}$ of heavy-metal solutions in order to investigate the impact of temperature. Solution temperatures of 20,30, 40,50 and $60{ }^{\circ} \mathrm{C}$ were each tested for $120 \mathrm{~min}$ and at $\mathrm{pH} 5$ and $\mathrm{pH} 3$ for $\mathrm{Zn}^{+2}$ and $\mathrm{Fe}^{+3}$, respectively.

Determination of optimum initial heavy-metal concentration

Different metal-ion concentrations of 10, 20, 50, 70, 80 and 100 mg.L ${ }^{-1}$ were tested at constant parameters of $\mathrm{pH} 5$ for $\mathrm{Zn}^{+2}$ and $\mathrm{pH} 3$ for $\mathrm{Fe}^{+3}$ with 1.0 g.L $\mathrm{L}^{-1}$ of the biosorbent material at $38 \pm 1{ }^{\circ} \mathrm{C}$ for $120 \mathrm{~min}$ in order to determine the effect of the initial concentration of metal on the efficiency of adsorption. Finally, the resulting suspension of each metal ion was filtered and analyzed by AAS for the corresponding metal-ion concentration.

Metal removal efficiency

The efficiency of biosorption $\left(\mathrm{q}_{\mathrm{e}}\right)$ is defined as the amount of metal adsorbed per gram of biosorbent and can be calculated in $\mathrm{mg}^{-1} \mathrm{~g}^{-1}$ as follows (Chen, 2005):

$$
\mathrm{q}_{\mathrm{e}}=\left(\mathrm{C}_{0}-\mathrm{C}_{\mathrm{e}}\right) \times \mathrm{V} / \mathrm{M}
$$

where $C_{e}$ is the equilibrium concentration of metal ions $\left(m g . L^{-1}\right), C_{0}$ is the initial metal-ion concentration $\left(\mathrm{mg} \cdot \mathrm{L}^{-1}\right), \mathrm{m}$ is the mass of biosorbent $(\mathrm{g})$ and $\mathrm{V}$ is the volume of solution (L). The following formula can be used to calculate the percentage of metal removed [64,65]:

$$
\text { Removal efficiency }(\%)=\left(C_{o}-C_{e}\right) / C_{o} \times 100
$$

Adsorption thermodynamic study

Thermodynamic parameters are very important because they provide the details of the spontaneity of the processes. Therefore, for the $\mathrm{Zn}^{+2}$ and $\mathrm{Fe}^{+3}$ adsorption on Ulva lactuca, Corallina officinalis and activated carbon, temperature conditions were varied between $20^{\circ} \mathrm{C}$ and $60^{\circ} \mathrm{C}$ while other factors remained fixed in order to obtain changes in free energy $\left(\mathrm{G}^{\circ}\right)$, enthalpy $\left(\mathrm{H}^{\circ}\right)$, and entropy $\left(\mathrm{S}^{\circ}\right)$ by using the expressions described below:

The adsorption process Gibbs free energy is estimated as [66]:

$$
\Delta \mathrm{G}^{\circ}=-\mathrm{RT} \ln \left(\mathrm{k}_{\mathrm{d}}\right)
$$

where $\Delta \mathrm{G}^{\circ}$ is the standard Gibbs-free-energy change for adsorption (J.mol $\left.{ }^{-1}\right), \mathrm{R}$ denotes the universal gas constant (8.314 J.mol $\left.{ }^{-1} \cdot \mathrm{K}^{-1}\right)$, T denotes the temperature in Kelvin (K), and $k_{d}$ denotes the adsorbate distribution coefficient, which is equal to $\mathrm{q}_{\mathrm{e}} / \mathrm{C}_{\mathrm{e}}\left(\mathrm{L} \cdot \mathrm{g}^{-1}\right)$. The 
plot of $\ln \left(\mathrm{k}_{\mathrm{d}}\right)$ versus $1 / \mathrm{T}$ yields a straight line with the values of $\Delta \mathrm{H}^{\circ}$ and $\Delta \mathrm{S}^{\circ}$ representing the slope and intercept, respectively:

$$
\ln \left(\mathrm{k}_{\mathrm{d}}\right)=\Delta \mathrm{S}^{\circ} / \mathrm{R}-\Delta \mathrm{H}^{\circ} / \mathrm{RT}
$$

These values can be used to compute $\Delta \mathrm{G}^{\circ}$ in the Gibbs relation:

$$
\Delta \mathrm{G}^{\circ}=\Delta \mathrm{H}^{\circ}-\mathrm{T} \Delta \mathrm{S}^{\circ}
$$

These parameters were calculated at temperatures of 293, 303, 313, 323 and $333 \mathrm{~K}[59,67]$.

Biosorption isotherm

At optimal $\mathrm{pH}$, various concentrations of $\mathrm{Zn}^{+2}$ and $\mathrm{Fe}^{+3}(10,20,30,50,70$, and $100 \mathrm{mg} . \mathrm{L}^{-1}$ ) were used to assess the adsorption isotherm. The Langmuir and Freundlich models were used to determine which concentration was best for describing the biosorption isotherm of two commonly used metals at a constant temperature. The Langmuir isotherm's linear form is given by the following equation [68]:

$$
\mathrm{C}_{\mathrm{e}} / \mathrm{q}_{\mathrm{e}}=1 /\left(\mathrm{b} \mathrm{q}_{\max }\right)+\mathrm{C}_{\mathrm{e}} / \mathrm{q}_{\max }
$$

where $C_{e}$ represents the metal residual content in solution, $q_{e}$ represents milligrams of metal accumulated per gram of biosorbent material, $\mathrm{b}$ represents the ratio of adsorption and desorption rates, and $\mathrm{q}_{\max }$ represents the maximum specific uptake corresponding to saturation of the binding site. The linear form of the Freundlich equation [69] is given as:

$$
\log \mathrm{q}_{\mathrm{e}}=\log \mathrm{K}_{\mathrm{F}}+1 / \mathrm{n} \times \log \left(\mathrm{C}_{\mathrm{e}}\right)
$$

where $K_{F}$ represents the Freundlich constant, which indicates adsorption capacity, and $1 / n$ represents the adsorption intensity.

\subsection{Statistical Analysis}

In order to ensure the accuracy of the data, all biosorption studies were carried out in triplicate. Data points in the figures depicted are mean \pm standard deviation (SD) for independent samples that were analyzed by using SPSS 23.0 (SPSS Inc., Chicago, IL, USA), and the minimum significant level was set at 0.05 .

\section{Results}

The Optimum Condition for $\mathrm{Zn}^{+2}$ and $\mathrm{Fe}^{+3}$ Ions Removal by Ulva lactuca and Corallina officinalis and their activated carbons.

Effect of Adsorbent Dosage

Figure 1 show the removal efficiency (\%) of various algal dosages $\left(\mathrm{g} . \mathrm{L}^{-1}\right)$, revealing that raising the adsorbent algal dosage from 0.2 to 1.0 g. $\mathrm{L}^{-1}$ improved the adsorption efficiency of the two metal ions by both DAP and AAC. The recorded maximum removal efficiency was up to $98.9 \%$ for $\mathrm{Zn}^{+2}$ and $97.6 \%$ for $\mathrm{Fe}^{+3}$ by AAC of Ulva lactuca. However, it reached $95.0 \%$ and $96.1 \%$ for $\mathrm{Zn}^{+2}$ and $\mathrm{Fe}^{+3}$, respectively, by AAC of Corallina officinalis. The same pattern was observed in the case of DAP for both algae, but with a lower percentage of adsorption of $\mathrm{Zn}^{+2}$ and $\mathrm{Fe}^{+3}$ for U. lactuca (93.6\% and $91.6 \%$, respectively), as well as by C. officinalis ( $87.9 \%$ and $91.6 \%$, respectively).

Effect of contact time

Figure 2 reflect that removal efficiency was highly influenced by contact time. Using 1.0 g. $\mathrm{L}^{-1}$ of adsorbent, the removal of both $\mathrm{Zn}^{+2}$ and $\mathrm{Fe}^{+3}$ reached a high level even after only $30 \mathrm{~min}$ of contact $(85.1 \%$ and $91.5 \%$ for DAP and AAC, respectively, of $U$. lactuca) and continued to increase significantly until $120 \mathrm{~min}$ (the equilibrium point) after which there was no further change in the removal efficiency. The maximum removal efficiency was recorded for $U$. lactuca AAC for both $\mathrm{Zn}^{+2}$ (98.9\%) and $\mathrm{Fe}^{+3}$ (97.6\%). The same trend was found for C. officinalis DAP with $87.8 \%$ and $88.4 \%$ removal efficiency for $\mathrm{Zn}^{+2}$ and 
$\mathrm{Fe}^{+3}$, respectively, and for its AAC with $94.7 \%$ and $96.2 \%$ removal efficiency for $\mathrm{Zn}^{+2}$ and $\mathrm{Fe}^{+3}$, respectively.
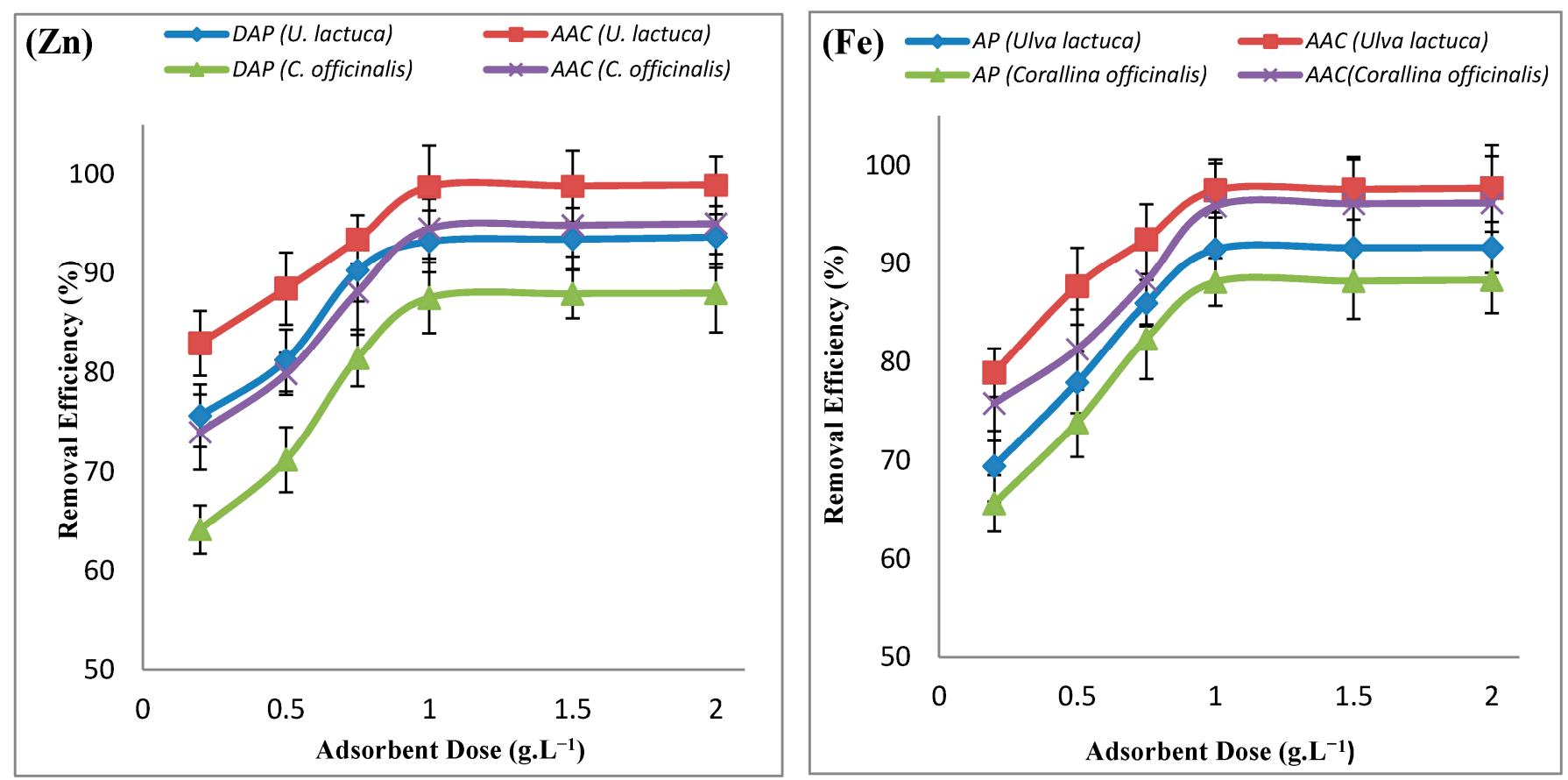

Figure 1. Effect of adsorbant dose of dried algal powder (DAP) and algal activated carbon (AAC) of $U$. lactuca and C. officinalis on the percentage of removal for $\mathrm{Zn}^{+2}$ and $\mathrm{Fe}^{+3}$ (at pH 5.0 and 50 mg.L ${ }^{-1}$ metal-ion concentration and 120 min. contact time). Each data point represents the mean \pm SD.
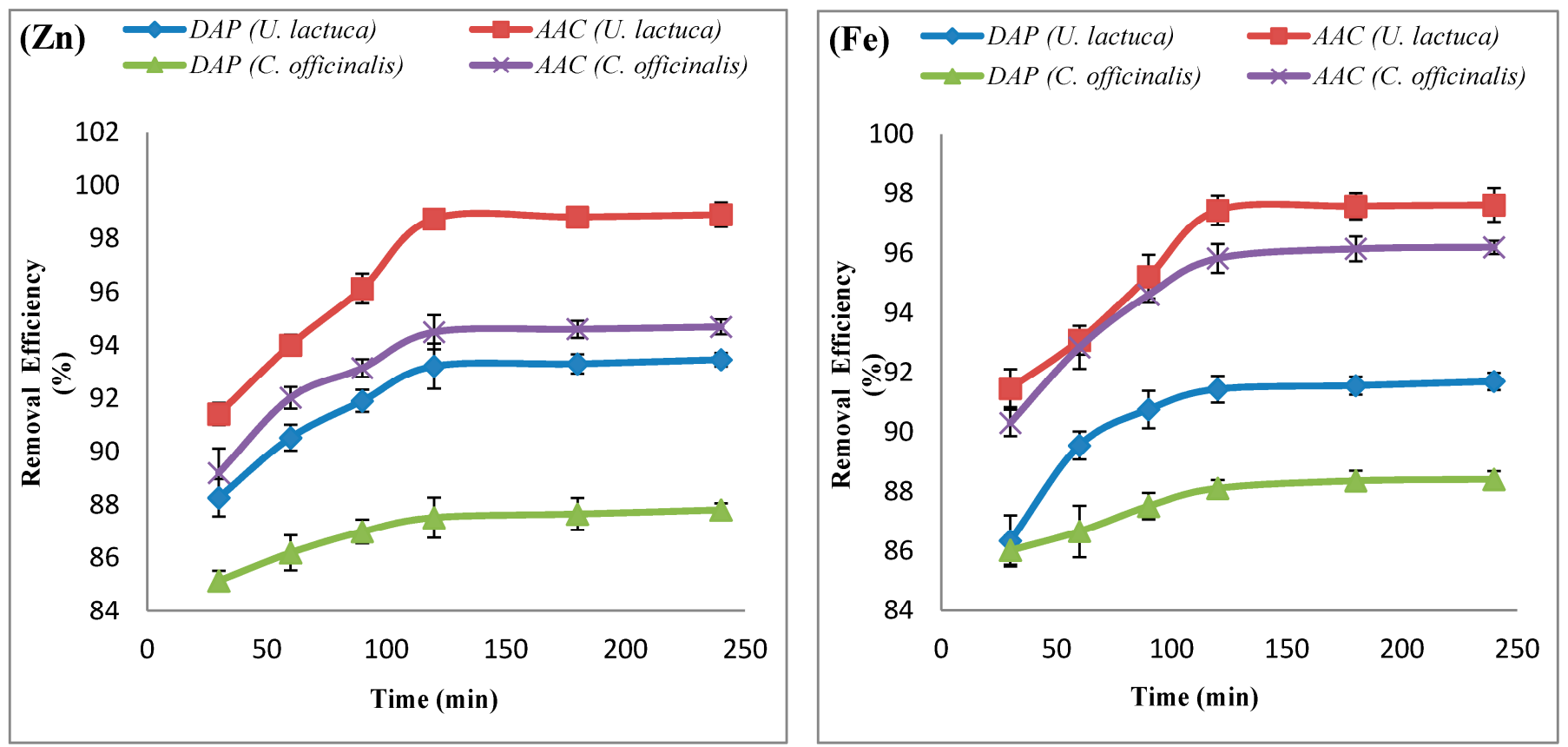

Figure 2. Effect of contact time (min.) on the percentage of removal for $\mathrm{Zn}^{+2}$ and $\mathrm{Fe}^{+3}$ (at pH 5.0 by using $50 \mathrm{mg} . \mathrm{L}^{-1}$ metal-ion concentration and 1.0 g. $\mathrm{L}^{-1}$ ) by using dried algal powder (DAP) and the activated carbon (AAC) of both U. lactuca and C. officinalis. Each data point represents the mean $\pm \mathrm{SD}$. 


\section{Effect of $p H$}

As shown in Figure 3, the impact of $\mathrm{pH}$ on the metal-ion adsorption efficiency was estimated at $\mathrm{pH}$ values of 2.0 to 8.0 for $\mathrm{Zn}^{+2}$ and 1.0 to 6.0 for $\mathrm{Fe}^{+3}$. Figure 3 clearly shows that the maximum percentage of removal for $\mathrm{Zn}^{+2}$ ions by the DAP and AAC of $U$. lactuca and C. officinalis was observed at $\mathrm{pH} 5$, and that the removal efficiency substantially decreased at lower $\mathrm{pH}$ values and slightly decreased at higher $\mathrm{pH}$ values. As the $\mathrm{pH}$ was raised from 2 to 5 , the effectiveness of metal-ion removal improved, with the percentage of removal efficiency increasing from $88.2 \%$ to $93.2 \%$ and from $91.1 \%$ to $98.7 \%$ for the DAP and AAC of $U$. lactuca, respectively, and increasing from $82.3 \%$ to $87.5 \%$ and $89.0 \%$ to $94.5 \%$ for the DAP and AAC of C. officinalis, respectively. Hence, the optimum acidity for $\mathrm{Zn}^{+2}$ ion removal was at $\mathrm{pH}$ 5. However, as shown in Figure 3, the maximum percentage of removal of $\mathrm{Fe}^{+3}$ ions was found at $\mathrm{pH} 3$ and declined considerably at lower and higher $\mathrm{pH}$ values. As the $\mathrm{pH}$ increased from 1 to 3 , the $\mathrm{Fe}^{+3}$ removal efficiency increased from $86.0 \%$ to $91.4 \%$ and from $90.3 \%$ to $97.4 \%$ for the DAP and AAC of U. lactuca, respectively, and increased from $82.7 \%$ to $88.1 \%$ and $87.7 \%$ to $95.8 \%$ for the DAP and AAC of C. officinalis, respectively. Hence, $\mathrm{pH} 3$ was established as the optimal $\mathrm{pH}$ value for $\mathrm{Fe}^{+3}$ removal, which can be used in further studies.
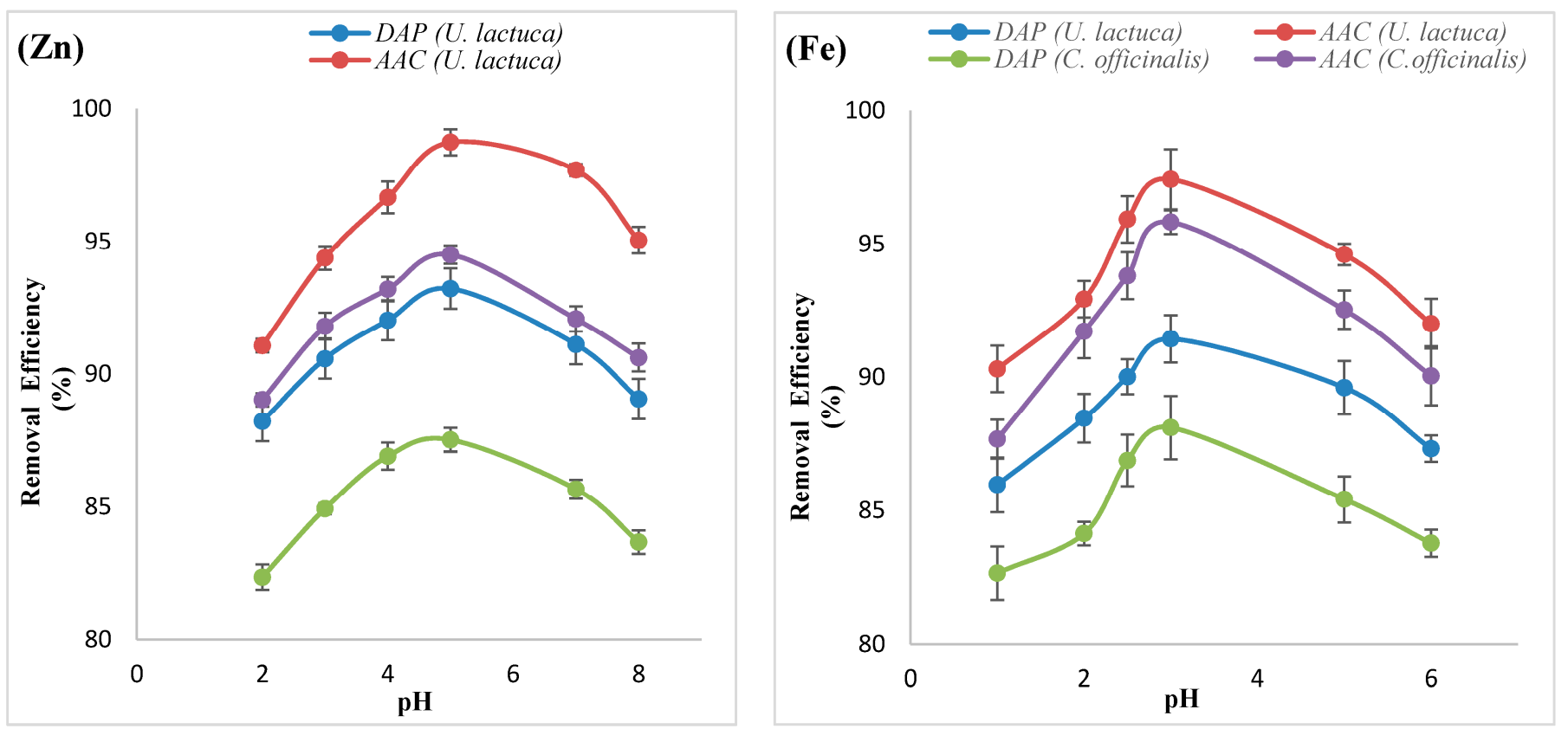

Figure 3. Effect of $\mathrm{pH}$ on the percentage of removal of $\mathrm{Zn}{ }^{+2}$ and $\mathrm{Fe}^{+3}$ (at 120 min.by using $50 \mathrm{mg} \cdot \mathrm{L}^{-1} \mathrm{metal}-\mathrm{ion}$ concentration and 1.0 g. $\mathrm{L}^{-1}$ ) using dried algal powder (DAP) and the activated carbon (AAC) of both $U$. lactuca and C. officinalis. Each data point represents the mean $\pm \mathrm{SD}$.

\section{Effect of initial concentration of metal ions}

An inspection of Figure 4 reveals that the initial concentration of metal ions was inversely related to the removal efficiency. As the initial metal-ion concentrations increased from 10 to $50 \mathrm{mg} . \mathrm{L}^{-1}$, the removal efficiencies decreased from $97.1 \%$ to $93.2 \%$ and from $96.8 \%$ to $91.4 \%$ for $\mathrm{Zn}^{+2}$ and $\mathrm{Fe}^{+3}$, respectively, using dried $U$. lactuca, and decreased from $91.1 \%$ to $87.5 \%$ and from $92.6 \%$ to $88.1 \%$ for $\mathrm{Zn}^{+2}$ and $\mathrm{Fe}^{+3}$, respectively, for the dried red alga C. officinalis. Additionally, when the initial ion concentrations varied from 10 to $100 \mathrm{mg}$. $\mathrm{L}^{-1}$, the removal efficiencies decreased from $99.7 \%$ to $98.6 \%$, and from $99.1 \%$ to $97.1 \%$ for $\mathrm{Zn}^{+2}$ and $\mathrm{Fe}^{+3}$, respectively, using the activated carbon of $U$. lactuca, and decreased from $96.7 \%$ to $94.3 \%$ and from $97.0 \%$ to $95.7 \%$ for $\mathrm{Zn}^{+2}$ and $\mathrm{Fe}^{+3}$, respectively, using the activated carbon of $C$. officinalis. 

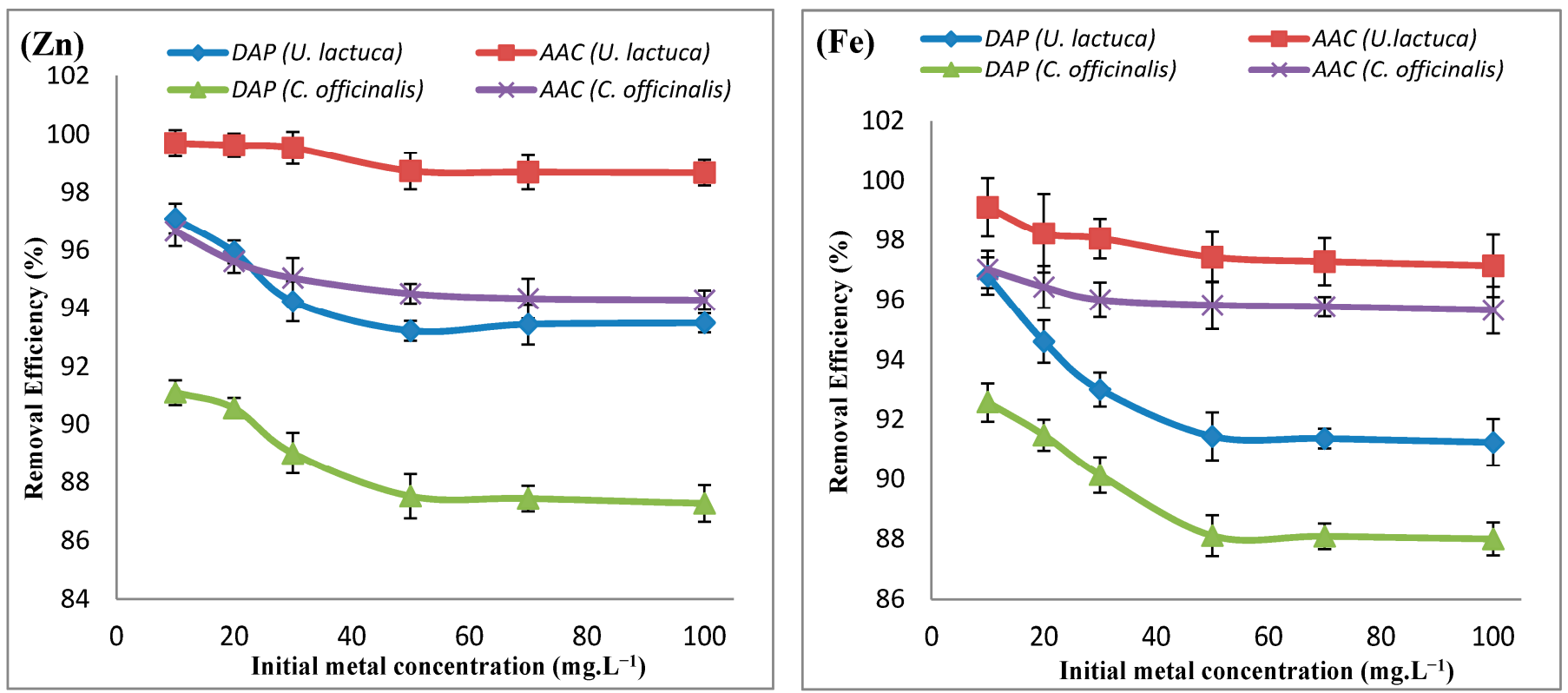

Figure 4. Effect of initial concentration of metal ion $\left(\mathrm{mg} \cdot \mathrm{L}^{-1}\right.$ ) on the percentage of removal of $\mathrm{Zn}^{+2}$ and $\mathrm{Fe}^{+3}$ (at 120 min., pH 5.0 and 1.0 g. $\mathrm{L}^{-1}$ ) using dried algal powder (DAP) and the activated carbon (AAC) of both U. lactuca and C. officinalis. Each data point represents the mean \pm SD.

\section{Effect of Temperature}

The evaluation of the removal efficiency of heavy metals under the influence of different temperatures revealed a large temperature effect. As shown in Figure 5, the removal of both $\mathrm{Zn}^{+2}$ and $\mathrm{Fe}^{+3}$ increased as temperature increased from 20 to $30^{\circ} \mathrm{C}$, until equilibrium was attained at $40{ }^{\circ} \mathrm{C}$, at which point the biosorption rate became almost constant. This was true for both the dried green algae and dried red algae, as well as for their activated carbon forms. The maximum removal efficiency was recorded using the AAC of $U$. lactuca for both $\mathrm{Zn}^{+2}(98.9 \%)$ and $\mathrm{Fe}^{+3}(97.7 \%)$. The same trend was found for C. officinalis with a DAP removal efficiency of $87.9 \%$ for $\mathrm{Zn}^{+2}$ and $88.47 \%$ for $\mathrm{Fe}^{+3}$ and an AAC removal efficiency of $94.7 \%$ for $\mathrm{Zn}^{+2}$ and $96.3 \%$ for $\mathrm{Fe}^{+3}$.
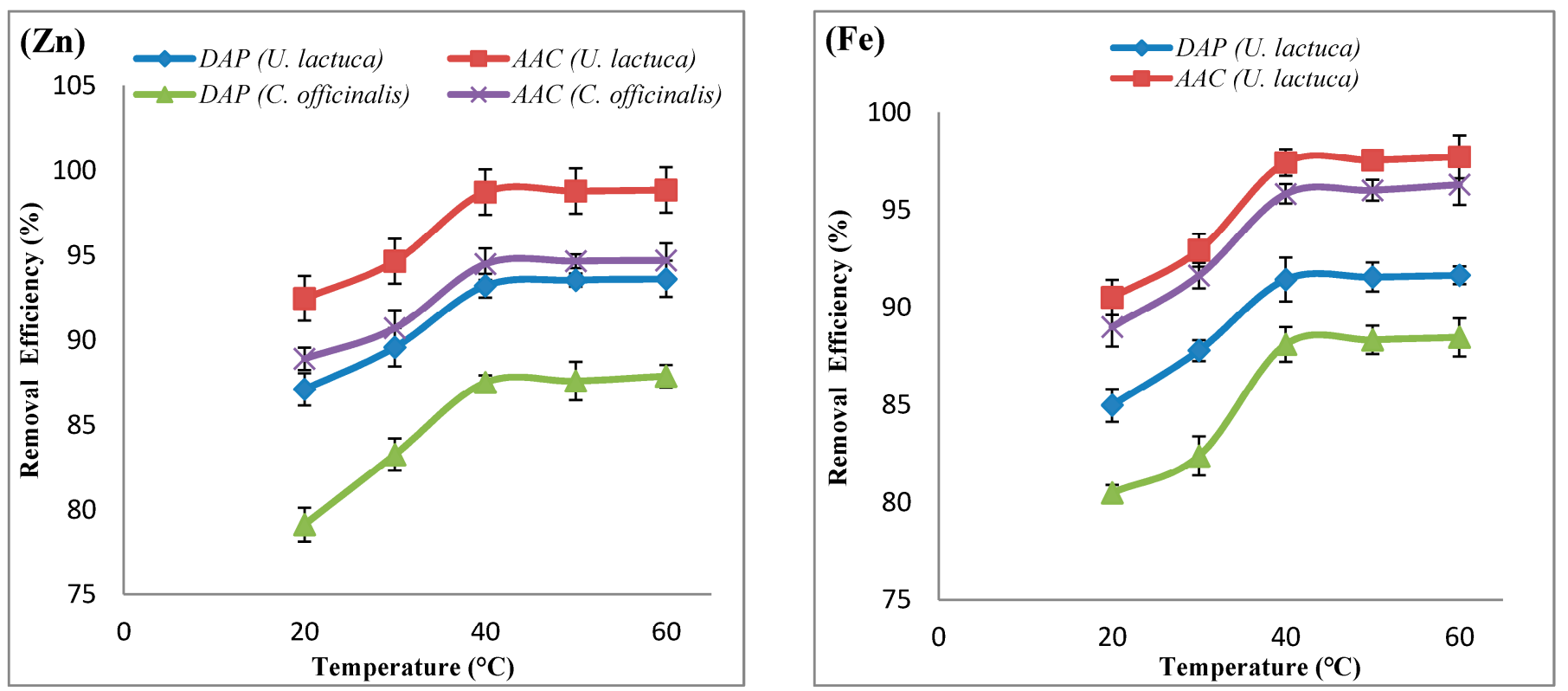

Figure 5. Effect of temperature on the percentage of removal of $\mathrm{Zn}^{+2}$ and $\mathrm{Fe}^{+3}$ (at $120 \mathrm{~min}$. pH 5.0 by using $50 \mathrm{mg} . \mathrm{L}^{-1}$ metal-ion concentration and 1.0 g. $\mathrm{L}^{-1}$ ) using dried algal powder (DAP) and the activated carbon (AAC) of both $U$. lactuca and C. officinalis. Each data point represents the mean \pm SD. 


\section{Adsorption thermodynamic}

The slope and intercept of the plot of $1 / \mathrm{T}$ vs. $\ln \left(\mathrm{k}_{\mathrm{d}}\right)$ (Equation (4) that was used to calculate the enthalpy change $\left(\Delta \mathrm{H}^{\circ}\right)$ and entropy change $\left(\Delta \mathrm{S}^{\circ}\right)$ resulted in the positive values shown in Table 1 . Table 1 and Figure 6 show the results obtained for the thermodynamic properties of zinc and iron, respectively. The values of the Gibbs-free-energy change $\left(\Delta G^{\circ}\right)$ for the adsorption processes of $\mathrm{Zn}^{+2}$ and $\mathrm{Fe}^{+3}$ onto $U$. lactuca, C. officinalis and activated carbon are shown at each of the tested experimental temperatures (273-333 K) and with an initial metal concentration of $50 \mathrm{mg} . \mathrm{L}^{-1}, \mathrm{pH} 5$ for $\mathrm{Zn}^{+2}$, and $\mathrm{pH} 3$ for $\mathrm{Fe}^{+3}$. These are confirmed by thermodynamic parameters such as free-energy $\left(\Delta \mathrm{G}^{\circ}, \mathrm{kcal} \mathrm{mol}^{-1}\right)$, enthalpy $\left(\Delta \mathrm{H}^{\circ}, \mathrm{kcal} \mathrm{mol}^{-1}\right)$ and entropy $\left(\Delta \mathrm{S}^{\circ}, \mathrm{cal} \mathrm{mol}^{-1} \mathrm{k}^{-1}\right)$ changes during the process. As the temperature increased (T1-T5), the values of $\Delta \mathrm{G}^{\circ}$ became more negative for each metal.

Table 1. Thermodynamic parameters for adsorption of $\mathrm{Zn}^{+2}, \mathrm{Fe}^{+3}$ onto DAP and AAC of both Ulva lactuca and Corallina officinalis.

\begin{tabular}{|c|c|c|c|c|c|c|c|c|}
\hline \multirow[t]{2}{*}{ Adsorbate } & \multirow[t]{2}{*}{ Adsorbent } & \multirow[t]{2}{*}{$\begin{array}{c}\Delta \mathrm{H}^{\circ} \\
\left(\mathrm{KJ} \cdot \mathrm{mol}^{-1}\right)\end{array}$} & \multirow[t]{2}{*}{$\begin{array}{c}\Delta S^{\circ} \\
\left(\mathrm{KJ}^{\circ} \cdot \mathrm{mol}^{-1}\right)\end{array}$} & \multicolumn{5}{|c|}{$\begin{array}{c}\Delta \mathrm{G}^{\circ} \\
\left(\mathrm{KJ} \cdot \mathrm{mol}^{-1}\right)\end{array}$} \\
\hline & & & & $\mathrm{T} 1\left(20^{\circ} \mathrm{C}\right)$ & $\mathrm{T} 2\left(30^{\circ} \mathrm{C}\right)$ & $\mathrm{T} 3\left(40^{\circ} \mathrm{C}\right)$ & $\mathrm{T} 4\left(50^{\circ} \mathrm{C}\right)$ & $\mathrm{T} 5\left(60^{\circ} \mathrm{C}\right)$ \\
\hline \multirow{4}{*}{$\mathrm{Zn}$} & DAP U. lactuca & 0.83 & 0.0340 & -9.13 & -9.47 & -9.81 & -10.15 & -10.49 \\
\hline & ACC U. lactuca & 1.37 & 0.0372 & -9.47 & -9.84 & -10.21 & -10.58 & -10.95 \\
\hline & DAP C. officinalis & 1.72 & 0.0384 & -9.41 & -9.79 & -10.17 & -10.55 & -10.93 \\
\hline & ACC C. officinalis & 1.36 & 0.0360 & -9.35 & -9.54 & -9.9 & -10.26 & -10.62 \\
\hline \multirow{4}{*}{$\mathrm{Fe}$} & DAP U. lactuca & 1.15 & 0.0357 & -9.31 & -9.66 & -10.07 & -10.38 & -10.73 \\
\hline & ACC U. lactuca & 1.57 & 0.0372 & -9.32 & -9.70 & -9.95 & -10.44 & -10.81 \\
\hline & DAP C. officinalis & 1.16 & 0.0355 & -9.24 & -9.59 & -9.74 & -10.30 & -10.66 \\
\hline & ACC C. officinalis & 1.34 & 0.0350 & -9.03 & -9.38 & -10.07 & -10.09 & -10.44 \\
\hline
\end{tabular}

\section{Biosorption Isotherm}

The characteristics of the biosorption of $\mathrm{Zn}^{+2}$ and $\mathrm{Fe}^{+3}$ ions by Ulva lactuca, Corallina officinalis and their activated carbons have been calculated using various isothermal models. In this study, models from Langmuir and Freundlich were applied. The basic assumption of the isotherm model of Langmuir is that biosorption occurs within the biosorbent at specific locations. No more biosorption occurs at a binding site once it is occupied by a biosorbate, which confirms the hypothesis that the biosorption process is monolayer.

The values of $q_{\max }$ and $\mathrm{b}$ from Equation (6) indicate the preference of heavy metals to attach to binding sites on the biosorbent. The constants were calculated from the slope $1 / \mathrm{q}_{\max }$ and intercept $1 / \mathrm{bq}_{\max }$ of the linear plot between $1 / \mathrm{C}_{\mathrm{e}}$ on the $\mathrm{y}$-axis and $1 / \mathrm{q}_{\mathrm{e}}$ on the $x$-axis, as illustrated in Figure $7 \mathrm{a}, \mathrm{b}$ for $\mathrm{Zn}^{+2}$ and in Figure $8 \mathrm{a}, \mathrm{b}$ for Fe $\mathrm{Fe}^{+3}$. From Table 2, the maximum adsorption capacity ( $q_{\max }$ ) of dried $\mathrm{U}$. lactuca for $\mathrm{Zn}^{+2}$ and $\mathrm{Fe}^{+3}$ was 23.6 and $46.5 \mathrm{mg} \cdot \mathrm{g}^{-1}$, respectively. However, the maximum adsorption capacity $\left(\mathrm{q}_{\max }\right.$ ) of AAC U. lactuca for $\mathrm{Zn}^{+2}$ and $\mathrm{Fe}^{+3}$ was 13.0 and $294 \mathrm{mg} \cdot \mathrm{g}^{-1}$ respectively. The maximum adsorption capacity $\left(\mathrm{q}_{\max }\right)$ of $\mathrm{C}$. officinalis and its activated carbon was obtained as 12.8 and $44.4 \mathrm{mg} / \mathrm{g}$, respectively, for $\mathrm{Zn}^{+2}$ and 16.6 and $94.3 \mathrm{mg} \cdot \mathrm{g}^{-1}$, respectively, for $\mathrm{Fe}^{+3}$. The values of the correlation coefficients $\left(\mathrm{R}^{2}\right)$ for $\mathrm{Zn}^{+2}$ and $\mathrm{Fe}^{+3}$ obtained from the plot were significant (ranged from 0.979 to 0.998 ), which represents the good fitness of this model for the biosorption of U. lactuca, C. officinalis, and their activated carbons. 

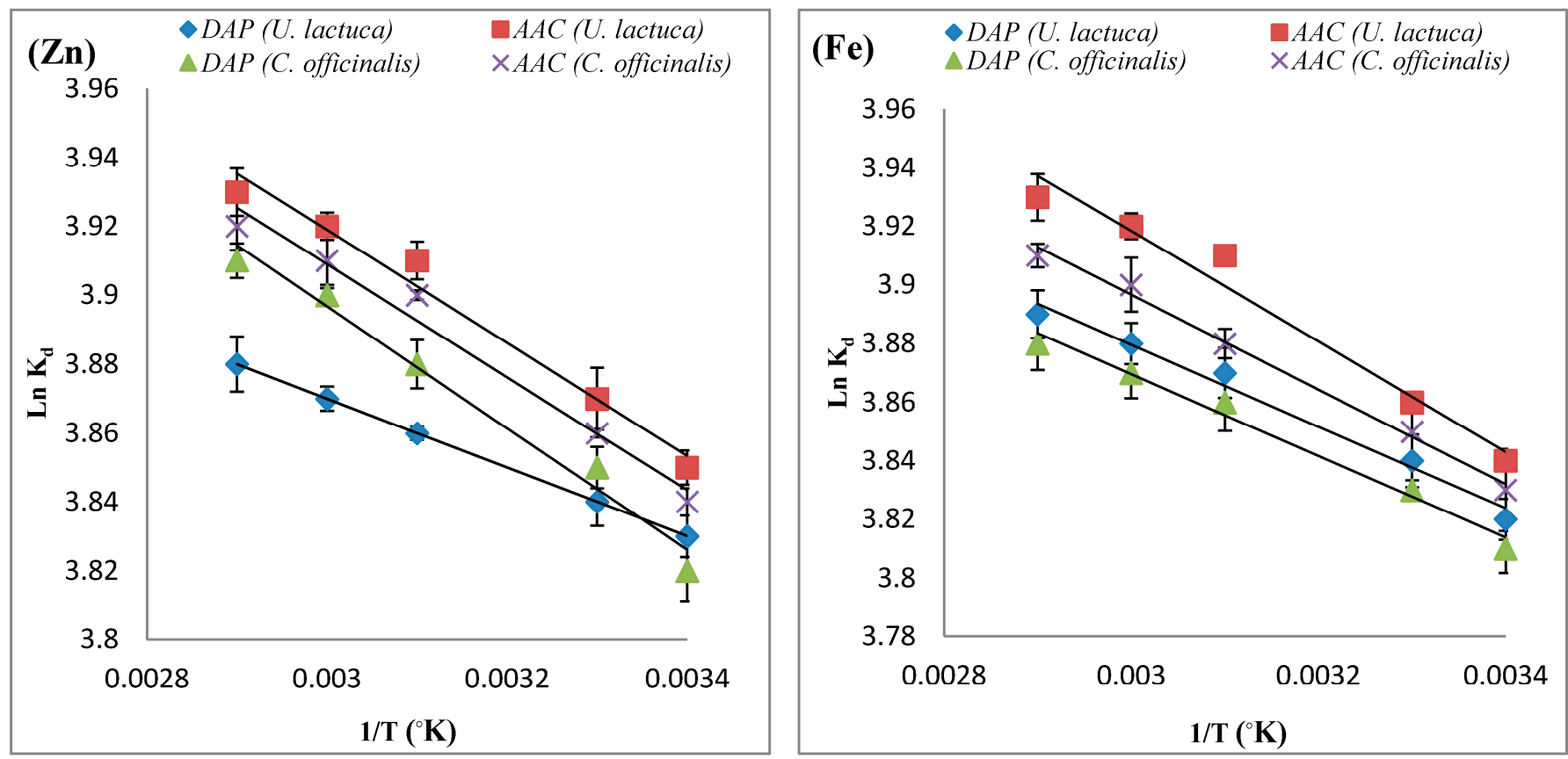

Figure 6. Plot of $\ln \mathrm{k}_{\mathrm{d}}$ versus $1 / \mathrm{T}$ for adsorption of $\mathrm{Zn}^{+2}$ and $\mathrm{Fe}^{+3}$ ions $\left(50 \mathrm{mg} \cdot \mathrm{L}^{-1}\right)$ on DAP and AAC of both $U$. lactuca and C. officinalis $\left(1 \mathrm{~g} . \mathrm{L}^{-1}\right)$. Each data point represents the mean $\pm \mathrm{SD}$.
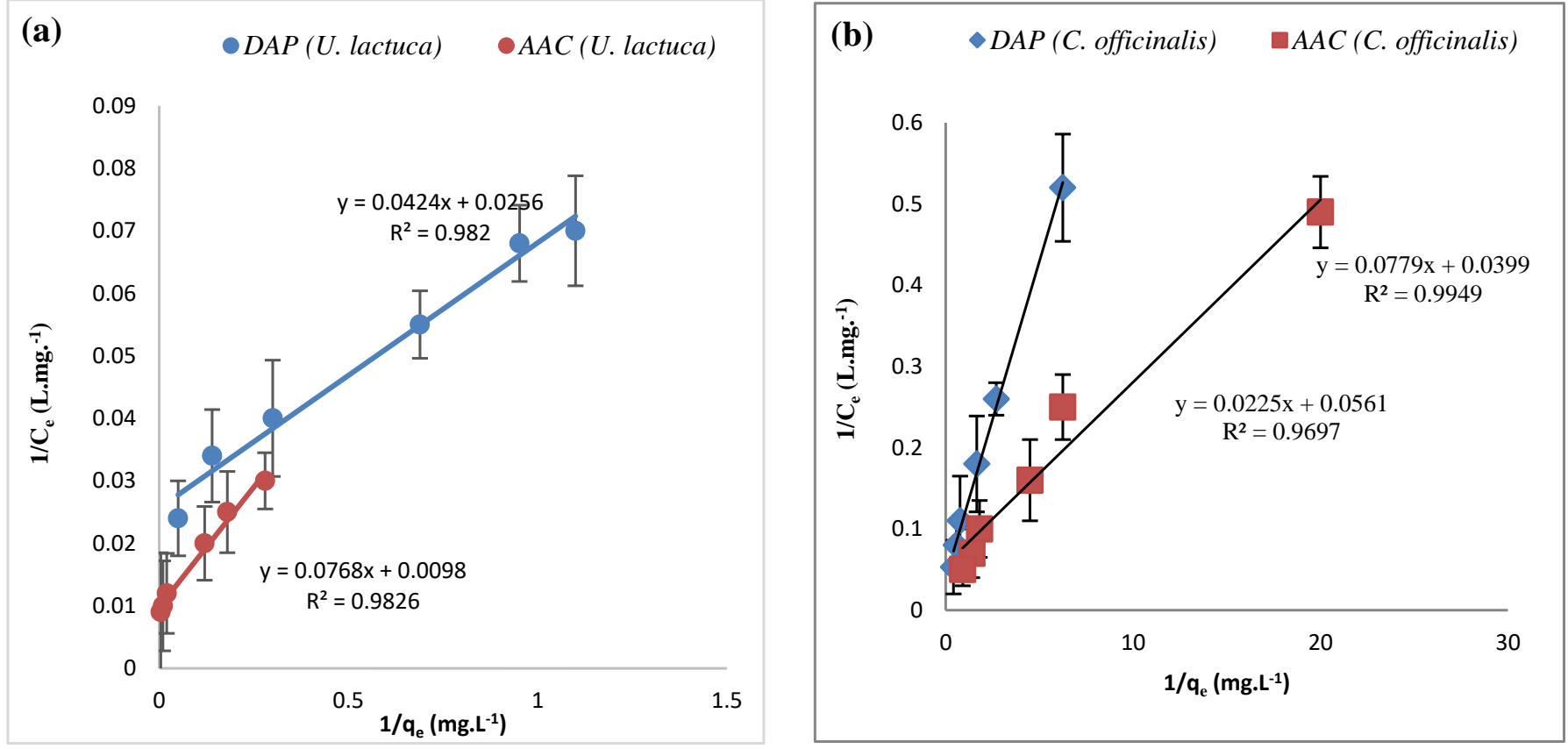

Figure 7. (a,b). Langmuir's adsorption isotherm for $\mathrm{Zn}^{+2}$ on DAP and AAC of (a) Ulva lactuca (b) Corallina officinalis. Each data point represents the mean $\pm \mathrm{SD}$. 

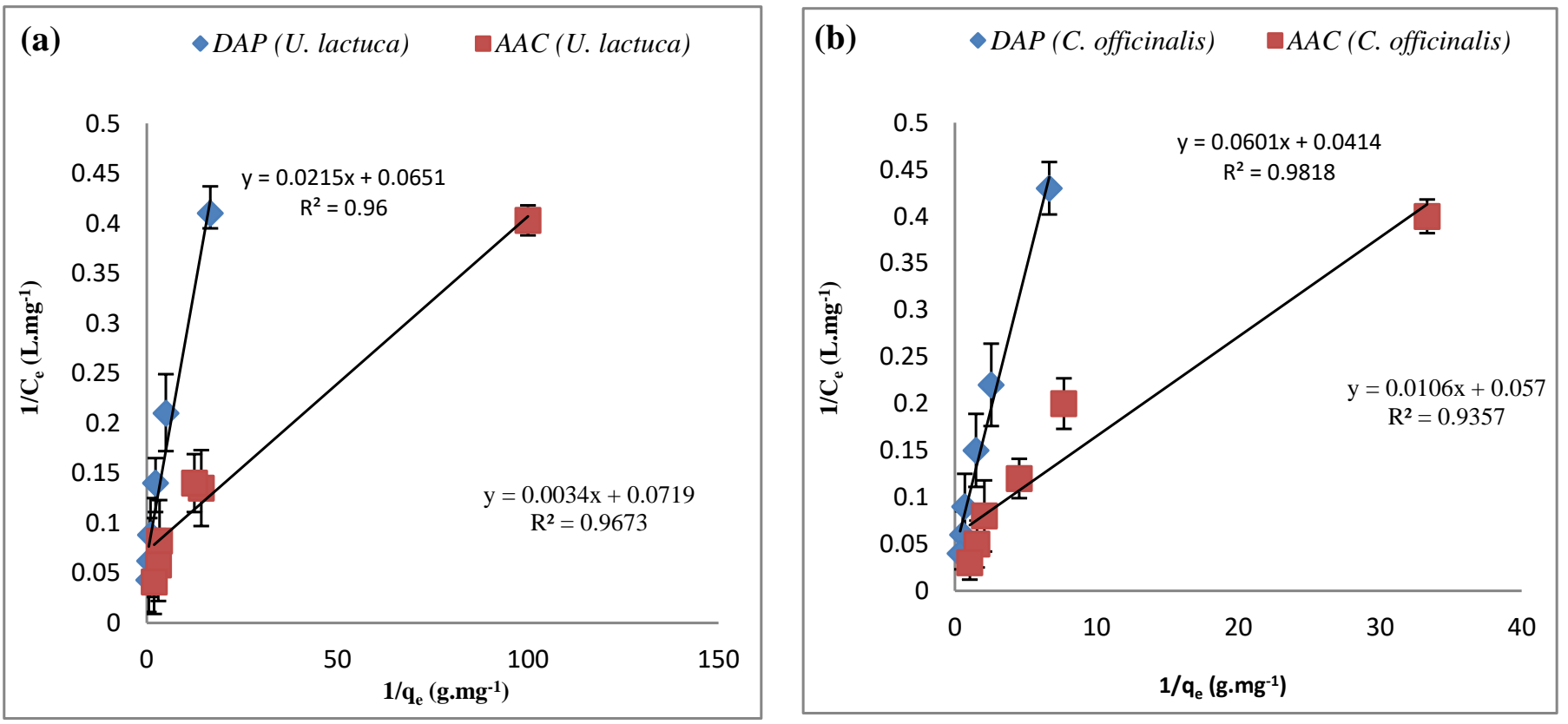

Figure 8. (a,b). Langmuir adsorption isotherms for $\mathrm{Fe}^{+3}$ on DAP and AAC of (a) Ulva lactuca (b) Corallina officinalis. Each data point represents the mean $\pm \mathrm{SD}$.

Table 2. Langmuir and Freundlich constants for the adsorption of $\mathrm{Zn}^{+2}$ and $\mathrm{Fe}^{+3}$ by DAP and AAC of both Ulva lactuca and Corallina officinalis.

\begin{tabular}{|c|c|c|c|c|c|c|c|}
\hline \multirow[b]{2}{*}{ Metal Ions } & \multirow[b]{2}{*}{ Biosorbent } & \multicolumn{3}{|c|}{ Langmuir Constants } & \multicolumn{3}{|c|}{ Freundlich Constants } \\
\hline & & $\underset{\left(\mathrm{mg} \mathrm{g}^{-1}\right)}{\mathrm{q}_{\max }}$ & $\begin{array}{c}b \\
\left(1 . \mathrm{mg}^{-1}\right)\end{array}$ & $\mathbf{R}^{2}$ & $\begin{array}{c}K_{f} \\
\left(\mathrm{mg}^{-1} \mathrm{~g}^{-1}\right)\end{array}$ & $1 / n$ & $\mathbf{R}^{2}$ \\
\hline \multirow{4}{*}{$\mathrm{Zn}^{+2}$} & DAP U. lactuca & 23.5 & 1.65 & 0.982 & 14.6 & 0.677 & 0.976 \\
\hline & AAC U. lactuca & 13.0 & 7.83 & 0.982 & 34.5 & 0.488 & 0.975 \\
\hline & DAP C. officinalis & 12.8 & 1.95 & 0.987 & 11.4 & 1.02 & 0.980 \\
\hline & AAC C. officinalis & 44.4 & 0.401 & 0.981 & 13.4 & 0.732 & 0.963 \\
\hline \multirow{4}{*}{$\mathrm{Fe}^{+3}$} & DAP U. lactuca & 46.5 & 0.330 & 0.981 & 17.7 & 0.756 & 0.961 \\
\hline & AAC U. lactuca & 294 & 0.047 & 0.994 & 29.2 & 0.561 & 0.953 \\
\hline & DAP C. officinalis & 16.6 & 1.45 & 0.979 & 11.2 & 0.882 & 0.916 \\
\hline & AAC C. officinalis & 94.3 & 0.185 & 0.998 & 21.3 & 0.655 & 0.978 \\
\hline
\end{tabular}

Using the same set of experimental data of dried green alga, dried red alga, and their activated carbons, the application of the empirical Freundlich isotherm was investigated based on sorption on heterogeneous surfaces and perhaps in multi-layer biosorption. From the linear form of Freundlich Equation (7), the Freundlich parameters may be calculated by graphing $\log \mathrm{q}_{\mathrm{e}} \mathrm{vs} . \log \mathrm{C}_{\mathrm{e}}$; the slope of the resulting line is equal to $1 / \mathrm{n}$, representing adsorption intensity, and the intercept is equal to $\log \mathrm{K}_{\mathrm{F}}$, where $\mathrm{K}_{\mathrm{F}}$ represents adsorption capacity. The plotted linear Freundlich equation is shown in Figure $9 \mathrm{a}, \mathrm{b}$ for $\mathrm{Zn}^{+2}$ and in Figure 10a,b for $\mathrm{Fe}^{+3}$. Table 2 lists the Freundlich constants. The values of correlation coefficients $\left(\mathrm{R}^{2}\right)$ for $\mathrm{Zn}^{+2}$ and $\mathrm{Fe}^{+3}$ obtained from the plot ranged from 0.916 to 0.980 , which are generally lower than those obtained using the Langmuir adsorption model. 

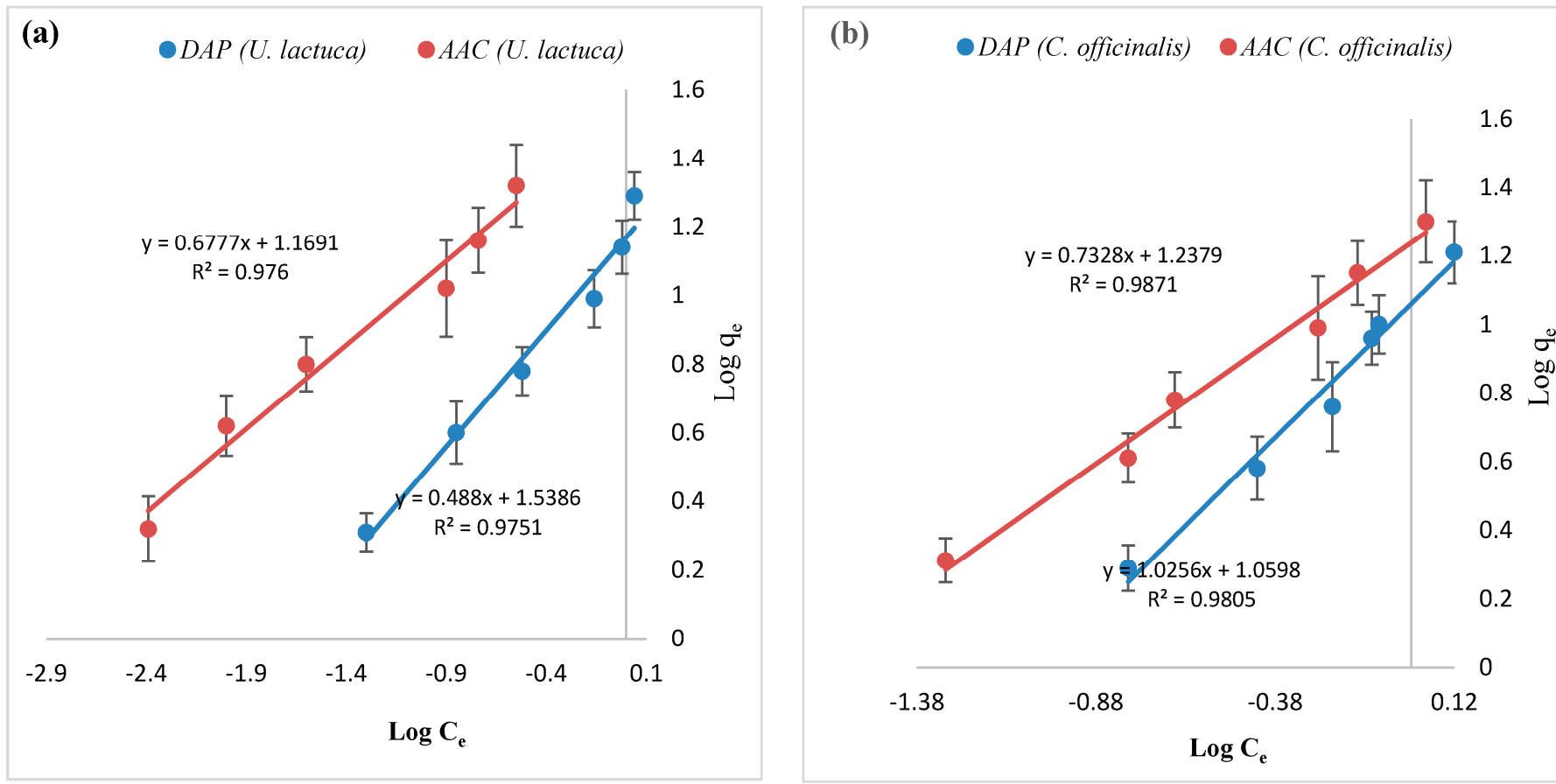

Figure 9. (a,b). Freundlich's adsorption isotherm for $\mathrm{Zn}^{+2}$ on DAP and AAC of (a) Ulva lactuca (b) Corallina officinalis. Each data point represents the mean \pm SD.
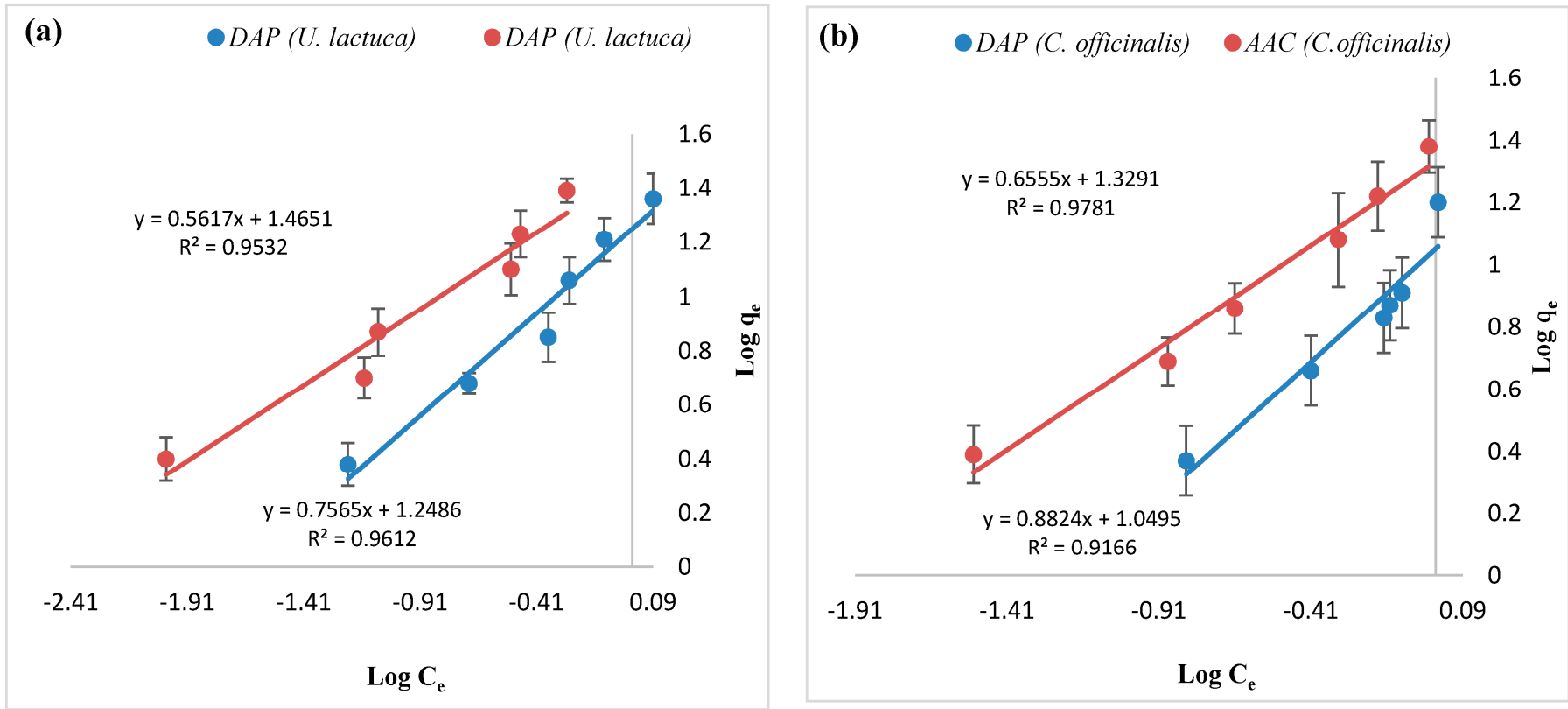

Figure 10. (a,b). Freundlich's adsorption isotherm for $\mathrm{Fe}^{+3}$ on DAP and AAC of (a) Ulva lactuca (b) Corallina officinalis. Each data point represents the mean $\pm \mathrm{SD}$.

\section{Discussion}

Biosorption has been found to be the most effective method for removing nonbiodegradable pollutants from aqueous solutions. Activated carbons, due to their potency and versatility, are the most popular adsorbent for this method. Activated carbons are typically derived from high-carbon materials and have a high adsorption ability, which is primarily determined by their porous nature [70]. The biosorption process is a complicated system, and various factors influence its efficiency, including the type of biomass 
used as an adsorbent material, the heavy-metal concentrations, and the physicochemical characteristics such as temperature, $\mathrm{pH}$, and contact time.

One of the most important factors impacting metal-ion biosorption is solution acidity [71-73]. Both the metal-binding sites on cell walls and the metal-ion chemistry in water influence the $\mathrm{pH}$ of the solution. Several authors have demonstrated that the $\mathrm{pH}$ of the solution has a significant impact on metal biosorption by algal biomass $[52,53,74,75]$. On the algal biomass, there are several amino, hydroxyl, carboxyl, and sulfate groups that are affected by changes in the $\mathrm{pH}$ of the solution $[56,76]$.

At different $\mathrm{pH}$ settings, the greatest biosorption effectiveness for $\mathrm{Zn}^{+2}$ and $\mathrm{Fe}^{+3}$ was observed. This could be due to differences in the metals' properties (size, electronegativity), or perhaps the more accessible metal exhibited better biosorption onto the adsorption sites [77]. Because $\mathrm{Fe}^{+3}$ has a larger electronegativity than $\mathrm{Zn}$ and hydronium ions, it exhibited a maximal biosorption at a lower $\mathrm{pH}\left(\mathrm{pH} 3\right.$ vs. $\mathrm{pH} 5$ for $\mathrm{Zn}^{+2}$ ); Hence, the affinity of Fe for the surface functional groups of the cell wall at a low $\mathrm{pH}$ is higher than that of $\mathrm{Zn}$ and hydronium ions. The decrease in biosorption yield at a higher $\mathrm{pH}$ was not only due to the formation of soluble hydroxylated metal-ion complexes (iron ions in the form of $\left.\mathrm{Fe}(\mathrm{OH})_{3}[78]\right)$, but also to the ionized state of the cell wall surface of the biomass at the measured $\mathrm{pH}$. In addition, chelation appears to be the main zinc-cation-sequestration mechanism used by the algal biomass, whereas iron cations have a higher affinity for the algal biomass and their binding mechanism includes a combination of ion exchange, chelation, and reduction reactions, as well as metallic-iron precipitation onto the cell wall matrix [79].

The initial concentration of metal ions acts as a powerful driving force between the aqueous and solid phases to overcome all of the resistance that is associated with the mass transfer of metal ions [80]. This finding implies that when the initial concentration of all metal ions rises, the percentage of $\mathrm{Zn}^{+2}$ and $\mathrm{Fe}^{+3}$ removal decreases. This could be explained by the fact that all of the adsorbents had a minimal number of active sites that were saturated above a specific concentration [81]. Another explanation for the decrease in the percentage of removal is the larger increase in the denominator $\left(\mathrm{C}_{\mathrm{o}}\right)$ value in comparison to the numerator $\left(C_{o}-C_{e}\right)$ value, per the equation $R=\left(C_{o}-C_{e}\right) / C_{o}$. In addition, for higher concentrations, the adsorption capacity $\left(\mathrm{q}_{\mathrm{e}}\right)$ of the $\mathrm{Zn}^{+2}$ and $\mathrm{Fe}^{+3}$ that was removed from the adsorbent (mg per gram) increased. For this purpose, for both metal ions, $50 \mathrm{mg} . \mathrm{L}^{-1}$ was selected as the optimum initial concentration. This finding agrees with Habtegebrel and Khan [82], who stated that the optimum initial concentration for $\mathrm{Zn}^{+2}$ was $50 \mathrm{mg} . \mathrm{L}^{-1}$ when using dried Prosopis juliflora, and also agrees with Bouzit et al. [83], who stated that the optimum initial concentration for $\mathrm{Fe}^{+3}$ was $50 \mathrm{mg} . \mathrm{L}^{-1}$ when using Scenedesmus obliquus.

The extent of biosorption is proportional to the specific area, i.e., the portion of the entire surface that is available for biosorption [80], because it is strongly dependent on the initial adsorbent concentration. The fact that the greatest metal adsorption occurred at a larger adsorbent dose $\left(1.0\right.$ g. $\left.\mathrm{L}^{-1}\right)$ could be due to a greater number of active sites for DAP and AAC, which accelerate metal-ion absorption $[84,85]$ due to adsorption site saturation at higher biosorbent concentrations $[84,85]$. This result was accepted because increasing the adsorbent dose provides a higher surface area and, consequently, more pore volume will be accessible for the biosorption [86,87]. Our findings are consistent with those of prior studies $[54,88,89]$. One gram of the sorbent was determined as the best dosage in all subsequent studies, and this agrees with the study by Lee and Chang [90], wherein they used Spirogyra and Cladophora filamentous macro algae.

Ideal biosorption materials can rapidly absorb large quantities of heavy metals from waste discharges and desorb heavy metals from biosorption materials using chemical agents [91]. For these reasons, the results of the adsorption of $\mathrm{Zn}^{+2}$ and $\mathrm{Fe}^{+3}$ ions by U. lactuca, C. officinalis powder (DAP) and their activated carbons (AAC) were dependent on the relation between the adsorption of heavy metal and contact time, and the outcome clearly showed that the adsorption procedure took place in two steps [92,93]. The ad- 
sorption rate was higher in the first stage, which may be related to the driving force of heavy-metal ions into the DAP and AAC surfaces, as well as the abundance of active adsorbent sites $[94,95]$. When these sites were exhausted, the adsorption effectiveness increased with an increase in contact time up to $120 \mathrm{~min}$, after which it remained more or less constant because the adsorbate had moved from the outer to the inner sites of the adsorbent particles. As a result, the best contact duration for both metal ions was determined to be $120 \mathrm{~min}$, which is consistent with El-Sikaily et al. [86]. These findings are also consistent with those of Bakatula et al. [96], who showed that there are two phases of biosorption: the first step includes the dissociation of the complexes formed between solution metals and water hydronium ions, followed by the interaction of metals with the functional groups of algae. The adsorption efficiency of DAP and AAC U. lactuca was found to be significantly higher than that of DAP and AAC C. officinalis algae because of the differences in the composition of proteins, lipids or other carbohydrates that influence the number of adsorption sites. It can be concluded that the activated carbon adsorption of $\mathrm{Zn}^{+2}$ and $\mathrm{Fe}^{+3}$ is far superior to that of dried green alga U. lactuca and red alga C. officinalis.

Temperature affects the biosorption efficiency of algae species for each metal ion $[85,97,98]$. Although the constants for metal-ligand complex formation are predominantly temperature-dependent, some studies have suggested that an increase in algal culture temperatures is responsible for an increase in metal-ion biosorption, without considering the changes in the formation constants $[99,100]$. The percentage of $\mathrm{Zn}^{+2}$ and $\mathrm{Fe}^{+3}$ ions that were removed from DAP and AAC of U. lactuca and C. officinalis increased as the temperature increased, indicating an endothermic adsorption process, which is a positive effect when considering the use of these algae in the environment, as well as their potential conservation and sustainability. However, other research has suggested that metal-ion uptake in some algae is exothermic, meaning that reducing the temperature enhances the uptake capability. Several studies have found a link between temperature and metal-ion intake by living algal cells, while others have found no link between temperature and metal-ion uptake by dead algal cells [101]. The following factors may contribute to an increase in biosorption as temperature rises: an increase in the number of active sites involved in metal-ion uptake; an increase in the tendency of active sites to absorb metal ions; a decrease in mass transfer resistance in the diffusion layer due to a reduction in the diffusion boundary layer thickness around the biosorbent groups; or a change in the composition of the biosorbent groups [89]. In comparing our results with other natural sources, the maximum biosorption capacity of $\mathrm{Zn}^{+2}$ was 54,83 , and $87 \%$ by bacteria [102], fungi [103] and plants $[50,104]$, respectively, while the obtained results from this study reached $98.74 \%$ efficiency by using the activated carbon of Ulva lactuca.

The maximum biosorption capacity of $\mathrm{Fe}^{+3}$ was $90.84,86$ and $70 \%$ by bacteria [105], fungi [103] and plants [106], respectively, while the obtained results from this study reached $97.43 \%$ efficiency by using the activated carbon of Ulva lactuca. From these findings, algae in general were more efficient. In fact, the brown macroalgae Sargassum and Colpomenia sinuosa, when in contact with $\mathrm{Zn}^{+2}$ toxic elements, have a maximum biosorption capacity of $90.65 \%$ [107] and $96.98 \%$ [108], respectively, whereas the microalgae Oscillatoria absorbs at $95 \%$ [109]. Furthermore, many studies have been performed on the green macroalgae Ulva fasciata, AAC Gracilaria, AAC U. lactuca, and Chlorella vulgaris, in contact with the toxic elements $\mathrm{Cd}^{+2}, \mathrm{Ni}^{+2}, \mathrm{Cr}^{+3}, \mathrm{Cd}^{+2}$, respectively, which indicated a very high biosorption efficiency [86,110-112].

The increase in the negative value of $\Delta \mathrm{G}^{\circ}$ with increasing temperature indicated that the adsorption of $\mathrm{Zn}^{+2}$ and $\mathrm{Fe}^{+3}$ ions by DAP and AAC of both $U$. lactuca and C. officinalis increased with increasing temperature, indicating a greater number of active sites available for spontaneous adsorption of $\mathrm{Zn}^{+2}$ and $\mathrm{Fe}^{+3}$ ions [113]. The presence of endothermic adsorbents for the adsorption of $\mathrm{Zn}^{+2}$ and $\mathrm{Fe}^{+3}$ ions in the examined temperature range of $20-60{ }^{\circ} \mathrm{C}$ was verified by the positive values of $\Delta \mathrm{H}^{\circ}$. The randomness of the adsorption process was confirmed by the positive values of $\Delta \mathrm{S}^{\circ}$. This finding agrees with Zaib et al. [114], who used the red algal biomass of Porphyridium cruentum. The equilibrium 
biosorption data was analyzed using biosorption isothermal models, which revealed a correlation between the mass of the solute adsorbed per unit mass of the equilibrium sorbent. Langmuir and Freundlich isotherms were used in order to determine biosorption isotherms [115]. Isotherm studies have shown that the Langmuir isotherm model is more appropriate for adsorption data than the Freundlich isotherm model, which indicates that U. lactuca, C. officinalis, and their activated carbons are all homogeneous. In other words, the biosorption of $\mathrm{Zn}^{+2}$ and $\mathrm{Fe}^{+3}$ onto U. lactuca, C. officinalis, and their activated carbons occurred as a monolayer biosorption on the functional groups' binding sites. This finding agrees with Areco et al. [116], Kumar et al. [117], and Anilkumar et al. [118], who stated that the best fit of the Langmuir model in the case of $\mathrm{Zn}^{+2}$ biosorption using the dried biomasses of green alga $U$. lactuca and red algae Gracilaria corticata suggests that effective interactions, most likely of the ion-exchange type, occur between both the algal biomass's superficial functional groups and the $\mathrm{Zn}^{+2}$ ions from the aqueous solution, and also agrees with Benaisa et al. [119], who reported that the Langmuir model is considered the best model for describing the biosorption of $\mathrm{Fe}^{3+}$ onto brown algae Sargassum vulgare. On the contrary, Liu et al., [120] reported the best fitting of the Freundlich model in the case of $\mathrm{Zn}$ biosorption using the brown alga Saccharina (Laminaria) japonica. The value of $\Delta \mathrm{G}^{\circ}$ was found to be negative for the adsorption of $\mathrm{Zn}^{+2}$ and $\mathrm{Fe}^{+3}$ ions, which confirmed the feasibility and spontaneous adsorption process, which could be useful for remediation in the era of temperature increases in order to save the environmental and the reproductive health of aquatic species.

\section{Conclusions}

Both U. lactuca and C. officinalis dried algal powders (DAP) and their $\mathrm{KOH}$-activated carbons (AACs) were produced and evaluated for $\mathrm{Zn}^{+2}$ and $\mathrm{Fe}^{+3}$ sorption. The optimum adsorption conditions were found to be approximately pH 5.0 and 3.0 for $\mathrm{Zn}^{+2}$ and $\mathrm{Fe}^{+3}$, respectively, a contact period of $120 \mathrm{~min}, 40^{\circ} \mathrm{C}$, an adsorbent dose $1.0 \mathrm{~g} . \mathrm{L}^{-1}$ and an initial concentration of $50 \mathrm{mg} . \mathrm{L}^{-1}$. The Langmuir isotherm model provides the best fit for the experimental results. The adsorption of $\mathrm{Zn}^{+2}$ and $\mathrm{Fe}^{+3}$ ions increased when the temperature was raised, according to the results of thermodynamic studies. The results of the thermodynamic parameter determinations revealed that the adsorption process is spontaneous and endothermic in nature, and that increasing the temperature promotes the adsorption of $\mathrm{Zn}^{+2}$ and $\mathrm{Fe}^{+3}$ ions onto U. lactuca, C. officinalis, and their activated carbons. In terms of heavy-metal removal, $\mathrm{KOH}$-activated carbon outperformed algal powder. Finally, it was concluded that $\mathrm{KOH}$-activated-carbon-dependent $U$. lactuca and $C$. officinalis can be used as an economically effective technology for removing and controlling the rising levels of heavy-metal pollution in the environment that are caused by many industries, in order to limit their negative effects on environmental health and aquatic organism sustainability. Based on these results, both the DAP and AAC of U. lactuca and C. officinalis can be used in wastewater treatment processes for the removal of heavy-metal residues, especially in industrial wastewater. We recommend conducting more extensive studies in order to test a larger number of algae, as they have proven to have higher biosorption efficiency compared to other natural sources. In addition to their formidable ability to rid wastewater of heavy metals, which may reach $100 \%$ removal efficiency, these algal biomasses are characterized as being safe and environmentally friendly, and are readily available at low cost. Finally, the use of these algal biomasses (either as dried powders or activated carbons) is strongly recommended as an efficient method for the removal of heavy metals from polluted effluents.

Author Contributions: Conceptualization, A.A.M., M.M.A., O.S.O., G.G.; methodology, A.A.M., J.M.; validation, M.H., A.A.M., J.M. and G.G.; formal analysis, A.A.M., J.M., U.L. and M.M.A.; investigation, all authors; resources, A.A.M., J.M., M.H. and G.G.; data curation, all authors; writingoriginal draft preparation, A.A.M., M.M.A., J.M., O.S.O. and G.G.; writing-review and editing, A.A.M. and G.G.; visualization, A.A.M., J.M., G.G.; supervision, A.A.M., G.G. All authors have read and agreed to the published version of the manuscript. 
Funding: This research received no external funding.

Institutional Review Board Statement: Not applicable.

Informed Consent Statement: Not applicable.

Data Availability Statement: Not applicable.

Acknowledgments: This work was realized in the framework of the international agreement (MoU) between Suez Canal University, Egypt (Coord. A.A.M.), and Federico II University, Italy (Coord. G.G.) in collaboration with Mustapha Hasnaoui (Univ. of Sultan Moulay Slimane, Morocco) and Oladokun Sulaiman Olanrewaju (RWTH Aachen Univ., Germany). We acknowledge the English critical revision of the visiting researcher at Federico II University, Emidio M. Sivieri, Biomedical Engineer at The Children's Hospital of Philadelphia, Philadelphia, PA, USA.

Conflicts of Interest: The authors declare no conflict of interest.

\section{References}

1. Ali, H.; Khan, E.; Ilahi, I. Environmental chemistry and ecotoxicology of hazardous heavy metals: Environmental persistence, toxicity, and bioaccumulation. J. Chem. 2019, 67, 303-305. [CrossRef]

2. Mosleh, Y.Y.; Mofeed, J.; Al-Maghrabi, O.; Fuller, M.P. Residues of heavy metals, PCDDs, PCDFs and DL-PCBs on some medicinal plants collected randomly from the Jeddah, central market. Life Sci. J. 2014, 11, 1-8.

3. Mosleh, Y.Y.; Mofeed, J.; Al-Maghrabi, O.A.; Mousa, T.; Kadasa, N.M.S. Dietary Intake of Pesticides Based on Vegetable Consumption: A Case Study, Jeddah, Kingd. of Saudi Arabia. Life Sci. J. 2014, 11, 680-688.

4. Abdel-Gawad, F.K.; Khalil, W.K.B.; Bassem, S.M.; Kumar, V.; Parisi, C.; Inglese, S.; Temraz, T.A.; Nassar, H.F.; Guerriero, G. The duckweed, Lemna minor modulates heavy metal-induced oxidative stress in the Nile tilapia Oreochromis niloticus. Water 2020, 12, 2983. [CrossRef]

5. Guezgouz, N.; Parisi, C.; Boubsil, S.; Grieco, G.; Hana, S.A.; Guerriero, G. Heavy Metals Assessment in the Medjerda River Basin (Northeastern Algeria): A Preliminary Water Analysis and Toad Skin Biopsy. Proc. Zool. Soc. 2021, 74, 104-113. [CrossRef]

6. Mosleh, Y.Y.; Mofeed, J. Biochmical biomarkers in algae Scenedesmae obliquus exposed to heavy metals Cd, Cu and Zn. Life Sci. J. 2014, 11, 994-1004.

7. Guerriero, G.; Bassem, S.M.; Abdel Gawad, F.K. Biological responses of white sea bream (Diplodus sargus, Linnaeus 1758) and sardine (Sardine pilchardus, Walbaum 1792) exposed to heavy metal contaminated water. Emir. J. Food Agric. 2018, 30, 688-694. [CrossRef]

8. Guerriero, G.; Bassem, S.M.; Khalil, W.K.B.; Temraz, T.A.; Ciarcia, G.; Abdel-Gawad, F.K. Temperature changes and marine fish species (Epinephelus coioides and Sparus aurata): Role of oxidative stress biomarkers in toxicological food studies. Emir. J. Food Agric. 2018, 30, 205-211. [CrossRef]

9. Mofeed, J. Impacts of $\mathrm{ZnO}$ nanoparticles on growth and antioxidant enzymes of the green alga Scenedesmus obliquus. Afr. J. Biol. Sci. 2020, 2, 1-12. [CrossRef]

10. Tosti, E.; Esposito, M.C. Reprotoxicity of Global Warming in Marine Species. J. Mar. Sci. Res. Dev. 2018, 8, S12-e001. [CrossRef]

11. Parisi, C.; Guerriero, G. Antioxidative Defense and Fertility Rate in the Assessment of Reprotoxicity Risk Posed by Global Warming. Antioxidants 2019, 8, 622. [CrossRef] [PubMed]

12. Gentilucci, M.; Moustafa, A.A.; Abdel-Gawad, F.K.; Mansour, S.R.; Coppola, M.R.; Caserta, L.; Inglese, S.; Pambianchi, G.; Guerriero, G. Advances in Egyptian Mediterranean Coast Climate Change Monitoring. Water 2021, 13, 1870. [CrossRef]

13. Fasulo, S.; Guerriero, G.; Cappello, S.; Colasanti, M.; Schettino, T.; Leonzio, C.; Mancini, G.; Gornati, R. The SYSTEMS BIOLOGY in the study of xenobiotic effects on marine organisms for evaluation of the environmental health status: Biotechnological applications for potential recovery strategies. Rev. Environ. Sci. Biotechnol. 2015, 14, 339-345. [CrossRef]

14. Piscopo, M.; Trifuoggi, M.; Notariale, R.; Labar, S.; Troisi, J.; Giarra, A.; Rabbito, D.; Puoti, R.; de Benedictis, D.; Brundo, M.V.; et al. Protamine-like proteins' analysis as an emerging biotechnique for cadmium impact assessment on male mollusk Mytilus galloprovincialis (Lamarck 1819). Acta Biochim. Pol. 2018, 65, 259-267. [CrossRef] [PubMed]

15. Piscopo, M.; Notariale, R.; Rabbito, D.; Ausió, J.; Olanrewaju, O.S.; Guerriero, G. Mytilus galloprovincialis (Lamarck, 1819) spermatozoa: Hsp70 expression and protamine-like protein property studies. Environ. Sci. Pollut. Res. 2018, 25, 12957-12966. [CrossRef] [PubMed]

16. Ahmad, S.; Pathak, V.V.; Kothari, R.; Kumar, A.; Krishna, S.B.N. Optimization of nutrient stress using C. pyrenoidosa for lipid and biodiesel production in integration with remediation in dairy industry wastewater using response surface methodology. 3 Biotech 2018, 8, 326. [CrossRef] [PubMed]

17. Hussain, J.; Husain, I.; Arif, M.; Gupta, N. Studies on heavy metal contamination in Godavari river basin. Appl. Water Sci. 2017, 7, 4539-4548. [CrossRef]

18. Horvath, B.; Gruiz, K. Impact of metalliferous ore mining activity on the environment in Gyongyosorozi, Hungary. Sci. Total Environ. 1996, 184, 215-227. [CrossRef] 
19. Guerriero, G.; Parisi, C.; Abdel-Gawad, F.K.; Hentati, O.; D’Errico, G. Seasonal and pharmaceutical-induced changes in selenoprotein glutathione peroxidase 4 activity in the reproductive dynamics of the soil biosentinel Podarcis sicula (Chordata: Reptilia). Mol. Reprod. Dev. 2019, 1, 1-10. [CrossRef] [PubMed]

20. Guerriero, G.; Brundo, M.V.; Labar, S.; Bianchi, A.R.; Trocchia, S.; Rabbito, D.; Palumbo, G.; Abdel-Gawad, F.K.; de Maio, A. Frog (Pelophylax bergeri, Gunther 1986) endocrine disruption assessment: Characterization and role of skin poly(ADP-ribose) polymerases. Environ. Sci. Pollut. Res. 2018, 25, 18303-18313. [CrossRef] [PubMed]

21. Li, Y.H.; Ji, Y.F.; Yang, L.S.; Li, S.J. Effects of mining activity on heavy metals in surface water in lead-zinc deposit area. J. Agro-Environ. Sci. 2007, 26, 103-107.

22. Scalici, M.; Traversetti, L.; Spani, F.; Malafoglia, V.; Colamartino, M.; Persichini, T.; Cappello, S.; Mancini, G.; Guerriero, G.; Colasanti, M. Shell fluctuating asymmetry in the sea-dwelling benthic bivalve Mytilus galloprovincialis (Lamarck, 1819) as morphological markers to detect environmental chemical contamination. Ecotoxicology 2017, 26, 396-404. [CrossRef]

23. Redha, A.A. Removal of heavy metals from aqueous media by biosorption. Arab. J. Basic Appl. Sci. 2020, 27, 183-193. [CrossRef]

24. Balkose, D.; Baltacioglu, H. Adsorption of heavy metal cations from aqueous solutions by wool fibers. J. Chem. Technol. Biotechnol. 1992, 54, 393-397. [CrossRef]

25. Javadian, H.; Ahmadi, M.; Ghiasvand, M.; Kahrizi, S.; Katal, R. Removal of Cr(VI) by modified brown algae Sargassum bevanom from aqueous solution and industrial wastewater. J. Taiwan Inst. Chem. Eng. 2013, 44, 977-989. [CrossRef]

26. Prabha, Y.; Soni, S.K.; Sharmita, G. Potential of Algae in Bio-remediation of Wastewater Current Research. Int. J. Curr. Microbiol. Appl. Sci. 2016, 5, 693-700. [CrossRef]

27. Jan, A.T.; Azam, M.; Siddiqui, K.; Ali, A.; Choi, I.; Haq, Q.M. Heavy metals and human health: Mechanistic insight into toxicity and counter defense system of antioxidants. Int. J. Mol. Sci. 2015, 16, 29592-29630. [CrossRef]

28. Guerriero, G.; Di Finizio, A.; Ciarcia, G. Oxidative Defenses in the Sea Bass, Dicentrarchus labrax. In Oxygen Transport to Tissue XXIV; Dunn, J.F., Swartz, H.M., Eds.; Springer: Boston, MA, USA, 2003; Volume 530, pp. 681-688.

29. Guerriero, G.; D’Errico, G.; Di Giaimo, R.; Rabbito, D.; Olanrewaju, O.S.; Ciarcia, G. Reactive oxygen species and glutathione antioxidants in the testis of the soil biosentinel Podarcis sicula (Rafinesque 1810). Environ. Sci. Pollut. Res. 2017, 25, 18286-18296. [CrossRef] [PubMed]

30. Rai, P.K.; Lee, S.S.; Zhang, M.; Tsang, Y.F.; Kim, K.H. Heavy metals in food crops: Health risks, fate, mechanisms, and management. Environ. Int. 2019, 125, 365-385. [CrossRef] [PubMed]

31. Abdullah, W.N.A.S.; Tiandee, S.; Lau, W.J.; Aziz, F.; Ismail, A.F. Potential use of nanofiltration like-forward osmosis membranes for copper ion removal. Chin. J. Chem. Eng. 2020, 28, 420-428. [CrossRef]

32. Bezzina, J.P.; Robshaw, T.; Dawson, R.; Ogden, M.D. Single metal isotherm study of the ion exchange removal of Cu(II), Fe(II), $\mathrm{Pb}(\mathrm{II})$ and $\mathrm{Zn}$ (II) from synthetic acetic acid leachate. Chem. Eng. J. 2020, 394, 124862. [CrossRef]

33. King, J.F.; Szczuka, A.; Zhang, Z.; Mitch, W.A. Efficacy of ozone for removal of pesticides, metals and indicator virus from reverse osmosis concentrates generated during potable reuse of municipal wastewaters. Water Res. 2020, 176, 115744. [CrossRef]

34. Hassan, A.A.; Al-Isawi, R.; Saleh, Z.A. The Use of Pre-Heated Black Cumin Seeds (Nigella sativa) for Sorption Basic Dyes from Aqueous Solutions. J. Ecol. Eng. 2021, 22, 149-158. [CrossRef]

35. Arief, V.O.; Trilestarim, K.; Sunarso, J.; Indraswati, N.; Ismadji, S. Recent Progress on biosorption of heavy metals from liquids using low cost biosorbents: Characterization, biosorption parameters and mechanism studies. Clean 2008, 36, 937-962. [CrossRef]

36. Alalwan, H.A.; Abbas, M.N.; Abudi, Z.N.; Alminshid, A.H. Adsorption of thallium ion $\left(\mathrm{Tl}^{+3}\right)$ from aqueous solutions by rice husk in a fixed bed column: Experiment and prediction of breakthrough curves. Environ. Technol. Innov. 2018, 12, 1-13. [CrossRef]

37. Mobark, M.; Mohamed, E.A.; Selim, A.Q.; Sellaoui, L.; Lamine, A.B.; Erto, A.; Bonilia-Petriciolet, A.; Seliem, M.K. Surfactantmodified serpentine for fluoride and $\mathrm{Cr}(\mathrm{VI})$ adsorption in single and binary systems: Experimental studies and theoretical modeling. Chem. Eng. J. 2019, 369, 333-343. [CrossRef]

38. Seliem, M.K.; Mobarak, M.; Selim, A.Q.; Mohamed, E.A.; Halfaya, R.A.; Gomaa, H.K.; Anastopoulos, I.; Giannakoudakis, D.A.; Lima, E.C.; Bonilia-Petriciolet, A.; et al. A novel multifunctional adsorbent of pomegranate peel extract and activated anthracite for $\mathrm{Mn}(\mathrm{VII})$ and $\mathrm{Cr}(\mathrm{VI})$ uptake from solutions: Experiments and theoretical treatment. J. Mol. Liq. 2020, 311, 113169. [CrossRef]

39. El Nemr, A.; El Sadaawy, M.M.; Khaled, A.; El Sikaily, A. Adsorption of the anionic dye Direct Red 23 onto new activated carbons developed from Cynara cardunculus: Kinetics, equilibrium and thermodynamics. Blue Biotechnol. J. 2014, 3, 121-142.

40. Shoaib, A.G.M.; El-Sikaily, A.; ElNemr, A.; Mohamed, A.E.-D.A.; Hassan, A.A. Preparation and characterization of highly surface area activated carbons followed type IV from marine red alga (Pterocladia capillacea) by zinc chloride activation. Biomass Convers. Biorefin. 2020, 1-13. [CrossRef]

41. Shoaib, A.G.M.; El-Sikaily, A.; ElNemr, A.; Mohamed, A.E.-D.A.; Hassan, A.A. Testing the carbonization condition for high surface area preparation of activated carbon followed type IV from green alga Ulva lactuca. Biomass Convers. Biorefin. 2020, 1-16. [CrossRef]

42. Babel, S.; Kurmiawan, T.A. Low-cost adsorbents for heavy metalsuptake from contaminated water: A review. J. Hazard. Mater. 2003, B97, 219-243. [CrossRef]

43. El Nemr, A. Non-Conventional Textile Waste Water Treatment; Nova Science Publishers, Inc.: Hauppauge, NY, USA, 2012; 267p.

44. Kim, K.W.; Lee, H.M.; Kim, B.S.; Hwang, S.H.; Kwac, L.K.; An, K.H.; Kim, B.J. Preparation and thermal properties of polyethylenebased carbonized fibers. Carbon Lett. 2015, 16, 62-66. [CrossRef] 
45. Mosleh, Y.; Mofeed, J.; Nafea, E.; Heham, S. Use of the microalga Scenedesmus obliquus (Turpin) Kutzing to remove some heavy metals from industrial wastewater. Egypt. J. Aquat. Biol. Fish. 2021, 25, 337-354. [CrossRef]

46. Abu-Dief, A.M.; Megalea, M.Z. Adsorption of the Heavy Metal Ions onto Bio sorbents: A review. Int. J. Nanomater. Chem. Int. 2018, 4, 27-39. [CrossRef]

47. Sekhara, K.C.; Kamala, C.T.; Chary, N.S.; Anjaneyulu, Y. Removal of heavy metals using a plant biomass with reference to environmental control. Int. J. Miner. Process. 2003, 68, 37-45. [CrossRef]

48. Mofeed, J. Biosorption of Heavy Metals from Aqueous Industrial Effluent by Non-living Biomass of Two Marine Green Algae Ulva lactuca and Dunaliella salina as Biosorpents. Catrina Int. J. Environ. Sci. 2017, 16, 43-52. [CrossRef]

49. Zayadi, N.; Othma, N. Characterization and Optimization of Heavy Metals Biosorption by Fish Scales. Adv. Mater. Res. 2013, 795, 260-265.

50. Bakar, A.A.; Ali, K.A.B.; Tarmizi, N.A.B.; Ahmad Zia Ul-Saufie, B.; Mohamad Japeri, A.Z.U.; Tammy, N.J.B. Potential of using bladderwort as a biosorbent to remove zinc in wastewater. AIP Conf. Proc. 2016, 1774, 030023.

51. Mishra, V. Biosorption of zinc ion: A deep comprehension. Appl. Water Sci. 2014, 4, 311-332. [CrossRef]

52. Apiratikul, R.; Pavasant, P. Batch and column studies of biosorption of heavy metals by Caulerpa lentillifera. Bioresour. Technol. 2008, 99, 2766-2777. [CrossRef] [PubMed]

53. Ibrahim, W.M.; Hassan, A.F.; Azab, Y.A. Biosorption of toxic heavy metals from aqueous solution by Ulva lactuca activated carbon. Egypt. J. Basic Appl. Sci. 2016, 3, 241-249. [CrossRef]

54. Mofeed, J.; Deyab, M.A.; Mohamed, B.; Moustafa, M.; Negm, S.; El-bilawy, E. Antimicrobial activities of three seaweeds extract against some human viral and bacterial pathogens. Biocell 2022, 46, 247-261. [CrossRef]

55. Belhadj, S.; Gargouri, M.; Guerriero, G.; Hentati, O. Polysaccharides from the Green Alga Ulva lactuca Improve Antioxidant Balance and Bone Mineral Density in Diabetic Rats. Biomed. Environ. Sci. 2021, 34, 637-640.

56. Ariano, A.; Musco, N.; Severino, L.; De Maio, A.; Tramice, A.; Tommonaro, G.; Damiano, S.; Genovese, A.; Olanrewaju, O.S.; Bovera, F; et al. Chemistry of Tropical Eucheumatoids: Potential for Food and Feed Applications. Biomolecules 2021, 11, 804. [CrossRef] [PubMed]

57. Olanrewaju, O.S.; Tommonaro, G.; Guerriero, G.; Fogliano, C.; Iodice, C.; Velotto, G.; Tramice, A. New Insight into Marine Biotechnology: Carrageenans Chemical Features and Acetylcholinesterase (AChE) Inhibition Activity of Two Edible Seaweeds of the Genus Kappaphycus. In EMCEI 2019: Recent Advances in Environmental Science from the Euro-Mediterranean and Surrounding Regions, 2nd ed.; Springer: Cham, Switzerland, 2021; pp. 2203-2207.

58. Olanrewaju, O.S.; De Maio, A.; Lionetti, E.; Bianchi, A.R.; Rabbito, D.; Ariano, A.; Majdoubi, F.-Z.; Guerriero, G. Sea Farms as a Safe and Sustainable Food Source: An Investigation on Use of Seaweeds for Liver Detoxification and Reduced DNA Damage in Lates calcarifer (Bloch, 1790). In EMCEI 2019: Recent Advances in Environmental Science from the Euro-Mediterranean and Surrounding Regions, 2nd ed.; Springer: Cham, Switzerland, 2021; pp. 671-675.

59. Sari, A.; Tuzen, M. Biosorption of $\mathrm{Pb}(\mathrm{II})$ and $\mathrm{Cd}(\mathrm{II})$ from aqueous solution using green alga (Ulva lactuca) biomass. J. Hazard. Mater. 2008, 152, 302-308. [CrossRef]

60. Turner, A.; Lewis, M.S.; Shams, L.; Brown, M.T. Uptake of platinum group elements by the marine macroalga, Ulva lactuca. Mar. Chem. 2007, 105, 271-280. [CrossRef]

61. Brinza, L.; Dring, M.J.; Gavrilescu, M. Marine micro- and macro-algal species as biosorbents for heavy metals. Environ. Eng. Manag. J. 2007, 6, 237-251. [CrossRef]

62. Londo, G. The decimal scale for relevés of permanent quadrats. In Sampling Methods and Taxon Analysis in Vegetation Science: Releve Surveys, 'Vegetationsaufnahmen', Floristic Analysis of Plant Communities; Handbook of vegetation sciences, pt. 4; Junk: Germany, 1984; pp. 45-49. Available online: https:/ / edepot.wur.nl/459509 (accessed on 2 December 2021).

63. De Clerck, O.; Coppejans, E. Marina Algae of the Jubail Marine Wildlife Sanctuary, Saudi Arabia; NCWCD: Berthoud, CO, USA, 1996; pp. 199-207.

64. Brodie, J.; Walker, R.H.; Williamson, C.; Irvine, L.M. Epitypification and redescription of Corallina officinalis L., the type of the genus, and C. elongata Elliset Solander (Corallinales, Rhodophyta). Cryptogam. Algol. 2013, 34, 49-56. [CrossRef]

65. Ibrahim, W.M.; Salim, E.H.; Azab, Y.A.; Ismail, A.M. Monitoring and removal of cyanobacterial toxins from drinking water by algal-activated carbon. Toxicol. Ind. Health 2015, 32, 1752-1762. [CrossRef] [PubMed]

66. Pavasant, P.; Apiratikul, R.; Marhaba, T.F. Biosorption of $\mathrm{Cu}^{2+}, \mathrm{Cd}^{2+}, \mathrm{Pb}^{2+}$ and $\mathrm{Zn}^{2+}$ Using Dried Marine Green Macroalga caulerpa lentillifera. Bioresour. Technol. 2006, 97, 2321-2329. [CrossRef] [PubMed]

67. Zhang, W.X.; Shen, Y.C.; Sr, L.I. Epidemiological investigation on mental disorders in 7 areas of China. Chin. J. Psychiatry 1998, 31, 69-77.

68. Hashim, M.A.; Chu, K.H. Biosorption of cadmium by brown, green, and red seaweeds. Chem. Eng. J. 2004, 97, 249-255. [CrossRef]

69. Voudrias, E.; Fytianosand, F.; Bozani, E. Sorption description isotherms of dyes from aqueous solutions and waste waters with different sorbent materials, Global Nest. Int. J. 2002, 4, 75-83.

70. Singh, D.B.; Prasad, G.; Rupainwar, D.C.; Singh, V.N. As (III) removal from aqueous solution by adsorption. Water Air Soil Pollut. 1988, 42, 373-386. [CrossRef]

71. Langmuir, I. The constitution and fundamental properties of solids and liquids. J. Am. Chem. Soc. 1916, 38, 2221-2295. [CrossRef]

72. Freundlich, H. Adsorption in solution. J. Phys. Chem. Soc. 1906, 40, 1361-1368. 
73. Sun, L.; Yao, Y.; Wang, L.; Mao, Y.; Huang, Z.; Yao, D.; Lu, W.; Chen, W. Efficient removal of dyes using activated carbon fibers coupled with 8-hydroxyquinoline ferric as a reusable Fentonlike catalyst. Chem. Eng. J. 2014, 240, 413-419. [CrossRef]

74. Fourest, E.; Roux, J.C. Heavy metal biosorption by fungal mycelial by products: Mechanisms and influence of pH. Appl. Microbiol. Biotechnol. 1992, 37, 399-403. [CrossRef]

75. Lia, Z.Y.; Guo, S.Y.; Li, L. Study on the process, thermodynamical isotherm and mechanism of Cr(III) uptake by Spirulina platensis. J. Food Eng. 2006, 75, 129-136. [CrossRef]

76. Shi, D.; Cui, B.; Li, L.; Xu, M.; Zhang, Y.; Peng, X.; Zhang, L.; Song, F.; Ji, L. Removal of calcium and magnesium from lithium concentrated solution by solvent extraction method using D2EHPA. Desalination 2020, 479, 114306. [CrossRef]

77. Figueira, M.M.; Volesky, B.; Mathieu, H.J. Instrumental analysis study of iron species biosorption by Sargassum biomass. Environ. Sci. Technol. 1999, 33, 1840-1846. [CrossRef]

78. Chen, J.P.; Hong, L.A.; Wu, S.N.; Wang, L. Elucidation of interactions between metal ions and Ca alginate-based ion-exchange resin by spectroscopic analysis and modelling simulation. Langmuir 2002, 18, 9413-9421. [CrossRef]

79. Mofeed, J.; Mosleh, Y.Y. Toxic responses and antioxidative enzymes activity of Scenedesmus obliquus exposed to fenhexamid and atrazine, alone and in mixture. Ecotoxicol. Environ. Saf. 2013, 95, 234-240. [CrossRef]

80. Chen, Z.; Ma, W.; Han, M. Biosorption of nickel and copper onto treated alga (Undaria pinnatifida): Application of isotherm and kinetic models. J. Hazard. Mater. 2008, 155, 327-333. [CrossRef] [PubMed]

81. Amini, M.; Younesi, H.; Bahramifar, N.; Lorestani, A.A.Z.; Ghorbani, F.; Daneshi, A.; Sharifzadeh, M. Application of response surface methodology for optimization of lead biosorption in an aqueous solution by Aspergillus niger. J. Hazard. Mater. 2008, 154, 694-702. [CrossRef]

82. Habtegebrel, M.M.; Khan, M.A. Removal of Zn (II) and Cu (II) Ions from Aqueous Solution by Dried Prosopis juliflora. Mod. Chem. 2018, 6, 6-14. [CrossRef]

83. Bouzit, L.; Jbari, N.; El Yousfi, F.; Slimani Alaoui, N.; Chaik, A.; Stitou, M. Adsorption of Fe ${ }^{3+}$ by a living microalgae biomass of Scenedesmus obliquus. Mediterr. J. Chem. 2018, 7, 156-163. [CrossRef]

84. Malkoc, E. Ni(II) removal from aqueous solutions using cone biomass of Thuja Orient. J. Hazard. Mater. 2006, 137, 899-908. [CrossRef]

85. Yu, W.W.; Qu, L.; Guo, W.; Peng, X. Experimental Determination of the Extinction Coefficient of CdTe, CdSe, and CdS Nanocrystals. Chem. Mater. 2003, 15, 2854-2860. [CrossRef]

86. El Sikaily, A.; El Nemr, A.; Khaled, A.; Abdelwahab, O. Removal of toxic chromium from wastewater using green alga Ulva lactuca and its activated Carbon. J. Hazard. Mater. 2007, 148, 216-228. [CrossRef]

87. Aravindhan, R.; Fathima, N.N.; Rao, J.R.; Nair, B.U. Equilibrium and thermodynamic studies on the removal of basic black dye using calcium alginate beads. Colloids Surf. 2007, 299, 232-238. [CrossRef]

88. Nuhoglu, Y.; Oguz, E. Removal of coppe r(II) from aqueous solutions by biosorption on the cone biomass of Thuja orientalis. Prosess Biochem. 2003, 38, 1627-1631. [CrossRef]

89. Malkoc, E.; Nuhoglu, Y. The Removal of Chromium (VI) From Synthetic Wastewater by Ulothrix zonata. Fresenius Environ. Bull. 2003, 12, 376-381.

90. Lee, Y.C.; Chang, S.P. The biosorption of heavy metals from aqueous solution by Spirogyra and Cladophora filamentous macroalgae. Bioresour. Technol. 2011, 102, 5297-5304. [CrossRef]

91. Dorris, K.L.; Yu, B.; Zhang, Y.; Shukla, A.; Shukla, S.S. The removal of heavy metal from aqueous solutions by sawdust adsorption-removal of copper. J. Hazard. Mater. 2000, 80, 33-42.

92. Abdel-Aty, A.M.; Ammar, N.S.; Abdel-Ghafar, H.H.; Ali, R.K. Biosorption of cadmium and lead from aqueous solution by fresh water alga Anabaena sphaerica biomass. J. Adv. Res. 2013, 4, 367-374. [CrossRef]

93. Singh, A.; Kumar, D.; Gaur, J.P. Copper(II) and lead(II) sorption from aqueous solution by non-living Spirogyra neglecta. Bioresour. Technol. 2007, 98, 3622-3629. [CrossRef]

94. Chang, Y.-C. Microbial Biodegradation of Xenobiotic Compounds; CRC Press: Boca Raton, FL, USA, 2019; p. 248.

95. Gupta, S.K.; Sriwastav, A.; Ansari, F.A.; Nasr, M.; Nema, A.K. Phycoremediation: An eco-friendly algal technology for bioremediation and bioenergy production. In Phytoremediation Potential of Bioenergy Plants; Bauddh, K., Singh, B., Korstad, J., Eds.; Springer: Singapore, 2017; pp. 431-456.

96. Aroua, M.K.; Leong, S.P.P.; Teo, L.Y.; Yin, C.Y.; Daud, W.M.A.W. Real time determination of kinetics of adsorption of lead(II) onto palm shell-based activated carbon using ion selective electrode. Bioresour. Technol. 2008, 99, 5786. [CrossRef]

97. Osinga, T.; Lipinski, W.; Guillot, E.; Olalde, G.; Steinfeld, A. Experimental determination of the extinction coefficient for a packed-bed particulate medium. Exp. Heat Transf. 2006, 19, 69-79. [CrossRef]

98. Bakatula, E.; Cukrowska, E.; Weiersbye, I.; Mihaly-Cozmuta, L.; Peter, A.; Tutu, H. Biosorption of trace elements from aqueous systems in gold mining sites by the filamentous green algae (Oedogonium sp.). J. Geochem. Explor. 2014, 144, 492-503. [CrossRef]

99. Chairat, M.; Bremner, J.B. Biosorption of lac dye by the red marine alga Gracilaria tenuistipitata: Biosorption kinetics, isotherms, and thermodynamic parameters. Coloration Technol. 2016, 132, 472-480. [CrossRef]

100. Gupta, V.K.; Rastogi, A.; Nayak, A. Biosorption of nickel onto treated alga (Oedogonium hatei): Application of isotherm and kinetic models. J. Colloid Interface Sci. 2010, 342, 533-539. [CrossRef] [PubMed]

101. Balarak, D.; Azarpira, H.; Mostafapour, F.K. Thermodynamics of removal of cadmium by adsorption on Barley husk biomass. Pharma Chem. 2016, 8, 243-247. 
102. Mwandira, W.; Nakashima, K.; Kawasaki, S.; Arabelo, A.; Banda, K.; Nyambe, I.; Chirwa, M.; Ito, M.; Sato, T.; Igarashi, T.; et al. Biosorption of $\mathrm{Pb}$ (II) and $\mathrm{Zn}$ (II) from aqueous solution by Oceanobacillus profundus isolated from an abandoned mine. Sci. Rep. 2020, 10, 21189. [CrossRef]

103. Bano, A.; Hussain, J.; Akbar, A.; Mehmood, K.; Anwar, M.; Hasni, M.S.; Ullah, S.; Sajid, S.; Ali, I. Biosorption of heavy metals by obligate halophilic fungi. Chemosphere 2018, 199, 218-222. [CrossRef] [PubMed]

104. Aksu, Z. Application of biosorption for the removal of organics pollutants: A review. Process Biochem. 2005, 40, 997-1026. [CrossRef]

105. Ali, M.H.; Abd Elkarim, M.S.; Haroun, S.A.; Attwa, K.M. Bioremediation of Fe, Zn and Cd ions from aqueous solution using died cells of cyanobacterial mats from extreme habitat, Siwa Oasis, Egypt. Egypt. J. Aquat. Biol. Fish. 2018, 22, 511-522. [CrossRef]

106. Adekola, F.A.; Hodonou, D.S.S.; Adegoke, H.I. Thermodynamic and kinetic studies of biosorption of iron and manganese from aqueous medium using rice husk ash. Appl. Water Sci. 2016, 6, 319-330. [CrossRef]

107. Bina, B.; Kermani, M.; Movahedian, H.; Khazaei, Z. Biosorption and Recovery of Copper and Zinc from Aqueous Solutions by Nonliving Biomass of Marine Brown Algae of Sargassum sp. Pak. J. Biol. Sci. 2006, 9, 1525-1530. [CrossRef]

108. Shaaban, A.M.; Badawy, R.K.; Mansour, H.A.; Mohamed, E.; Abdel-Rahman, M.E.; Yasmin, I.E.; Aboulsoud, Y.I.E. Competitive algal biosorption of $\mathrm{Al}^{3+}, \mathrm{Fe}^{3+}$, and $\mathrm{Zn}^{2+}$ and treatment application of some industrial effluents from Borg El-Arab region. Egypt. J. Appl. Phycol. 2017, 29, 3221-3234. [CrossRef]

109. Chen, F.; Chen, B.; Gan, G.; Zhang, L.; Liang, Y.; Wu, S. Biosorption of $\mathrm{Zn}^{+2}$ and Ni ${ }^{+2}$, Cu ${ }^{+2}$ by Four Kinds of Active Microalgae. J. Mater. Sci. Chem. Eng. 2016, 4, 12-19. [CrossRef]

110. El-Naggar, N.E.A.; Hamouda, R.A.; Mousa, I.E.; Abdel-Hamid, M.S.; Rabei, N.H. Statistical optimization for cadmium removal using Ulva fasciata biomass: Characterization, immobilization and application for almost-complete cadmium removal from aqueous solutions. Sci. Rep. 2018, 8, 12456. [CrossRef] [PubMed]

111. Esmaeili, A.; Ghasemi, S. Evaluation of the Activated Carbon Prepared of Algae Marine Gracilaria for the Biosorption of Ni (II) from Aqueous Solutions. World Appl. Sci. J. 2009, 6, 515-518.

112. Cheng, J.; Yin, W.; Chang, Z.; Lundholm, N.; Jiang, Z. Biosorption capacity and kinetics of cadmium (II) on live and dead Chlorella vulgaris. J. Appl. Phycol. 2017, 29, 211-221. [CrossRef]

113. Li, Y.; Xia, B.; Zhao, Q.; Liu, F.; Du, Q.; Wang, D.; Li, D.; Wang, Z.; Zhang, P.; Xia, Y. Removal of copper ions from aqueous solution by calcium alginate immobilized kaolin. J. Environ. Sci. 2011, 23, 404-411. [CrossRef]

114. Zaib, M.; Makshoof Athar, M.; Saeed, A.; Farooq, U.; Salman, M.; Nouman Makshoof, M. Equilibrium, kinetic and thermodynamic biosorption studies of $\mathrm{Hg}$ (II) on red algal biomass of Porphyridium cruentum. Green Chem. Lett. Rev. 2016, 9, 179-189. [CrossRef]

115. Su-Hsia, L.; Ruey-Shin, J. Adsorption of phenol and its derivatives from water using synthetic resins and low-cost natural adsorbents: A review. J. Environ. Manag. 2009, 90, 1336-1349.

116. Arecoa, M.M.; Hanelab, S.; Duranb, J.; dos Santos, A.M. Biosorption of Cu(II), Zn(II), Cd(II) and Pb(II) by dead biomasses of green alga Ulva lactuca and the development of a sustainable matrix for adsorption implementation. J. Hazard. Mater. 2012, 213, 123-132. [CrossRef]

117. Kumar, Y.P.; King, P.; Prasad, V.S.R.K. Adsorption of zinc from aqueous solution using marine green algae-Ulva fasciata sp. Chem. Eng. J. 2007, 129, 161-166. [CrossRef]

118. Anilkumar, B.; Chitti, B.N.; Kavitha, G. Biosorption of Zinc on to Gracilaria Corticata (Red Algae) Powder and Optimization using Central Composite Design. J. Appl. Sci. Eng. Methodol. 2016, 2, 412-425.

119. Benaisa, S.B.; Arhoun, B.; El Mail, R.; Rodriguez-Maroto, J.M. Potential of brown algae biomass as new biosorbent of Iron: Kinetic, equilibrium and thermodynamic study. J. Mater. Environ. Sci. 2018, 9, 2131-2141.

120. Liu, Y.; Cao, Q.; Luo, F.; Chen, J. Biosorption of $\mathrm{Cd}^{2+}, \mathrm{Cu}^{2+}, \mathrm{Ni}^{2+}$ and $\mathrm{Zn}^{2+}$ ions from aqueous solutions by pretreated biomass of brown algae. J. Hazard. Mater. 2009, 163, 931-938. [CrossRef] [PubMed] 